\title{
Arheološke raziskave na najdišču Školska Tumba v Mogili v letu 20I4 (Severna Makedonija)
}

Alenka Tomaž, Univerza na Primorskem, Fakulteta za humanistične študije, Inštitut za arheologijo in dediščino, Koper

Goce Naumov, Muzej na Makedonija, Skopje

Arheološke raziskave v Pelagoniji (Severna Makedonija) so po nekaj desetletnem premoru v zadnjem desetletju doživele ponoven zagon. V članku predstavljamo rezultate arheološkega izkopavanja na lokaciji Školska Tumba v vasi Mogila, ki jih je izvedla makedonsko-slovenska ekipa v letu 20I4. Rezultati so bistyeno dopolnili dosedanje poznavanje neolitske poselitve obravnavanega prostora, kakor tudi srednjeveških aktivnosti na območju samih prazgodovinskih tumbv regiji.

Ključne besede: neolitik, naselbina Školska Tumba, Mogila, Severna Makedonija

Archaeological research in Pelagonia (North Macedonia) has undergone afresh restart over the past decade after being paused for several decades. In this article we present the results of an archaeological excavation at the location Školska Tumba in the village of Mogila, carried out by the Macedonian-Slovenian team in 2014. These results significantly enriched the existing knowledge on Neolithic settlement of this area as well as medieval activities at prehistoric tell settlements in general in the region.

Keywords: Neolithic, Settlement Školska Tumba, Mogila, North Macedonia

$\mathrm{P}$ elagonija je v arheološki literaturi od nekdaj poznana kot območje številnih arheoloških najdišč. Čeprav je regija bolj poznana po antičnih in srednjeveških lokacijah, so izjemno zanimiva tudi najdišča, ki sodijo v prazgodovinsko obdobje (Simoska in Sanev 1976). Le-ta so bila v preteklosti večkrat raziskovana, tako, da razmeroma dobro poznamo njihovo časovno umestitev, kakor tudi kulturne značilnosti materialne kulture skupnosti, ki so naseljevale obravnavano območje. Večji del teh najdišč predstavljajo t.i. tumbe - zaradi intenzivne sosledne poselitve umetno ustvarjeni griči, katerih nastanek lahko največkrat vežemo za neolitsko obdobje, v posameznih primerih pa so kontinuirano poseljeni še času eneolitika in $v$ bronasti dobi ${ }^{\mathrm{I}}$. Železnodobna naselja in nekropole na lokacijah

V tekstu uporabljamo izvirni izraz tumba, saj v slovenskem izrazoslovju za ta tip arheološkega najdišča ni strokovno ustreznega izraza. tumb do sedaj niso poznani. $V$ redkih primerih so sicer zabeleženi primerki antične keramike, vendar pa ni nikakršnih dokazov, da bi bili antični objekti grajeni na samih tumbah. Vezano na srednjeveško poselitev območja, se morda zdi posebno zanimivo tudi opažanje, da so nekropole tega časa pogosto vezane na lokacije prazgodovinskih tumb, kar je verjetno povezano predvsem z njihovo geografsko mikro-morfologijo. Višina teh umetno ustvarjenih gričev in izdvajanje od okoliških močvirnatih predelov je namreč omogočala srednjeveškim skupnostim varen prostor za pokopavanje, skupaj s simboličnim pomenom obrednih prostorov $\mathrm{v}$ domeni krščanske ideologije (Naumov et al. 2014, 345-372).

Arheološke raziskave na prazgodovinskih najdiščih - tumbah so bile v Pelagoniji dokaj številne in so se izvajale $\mathrm{v}$ več etapah, ki pa so na žalost le redke potekale kontinuirano (Naumov 


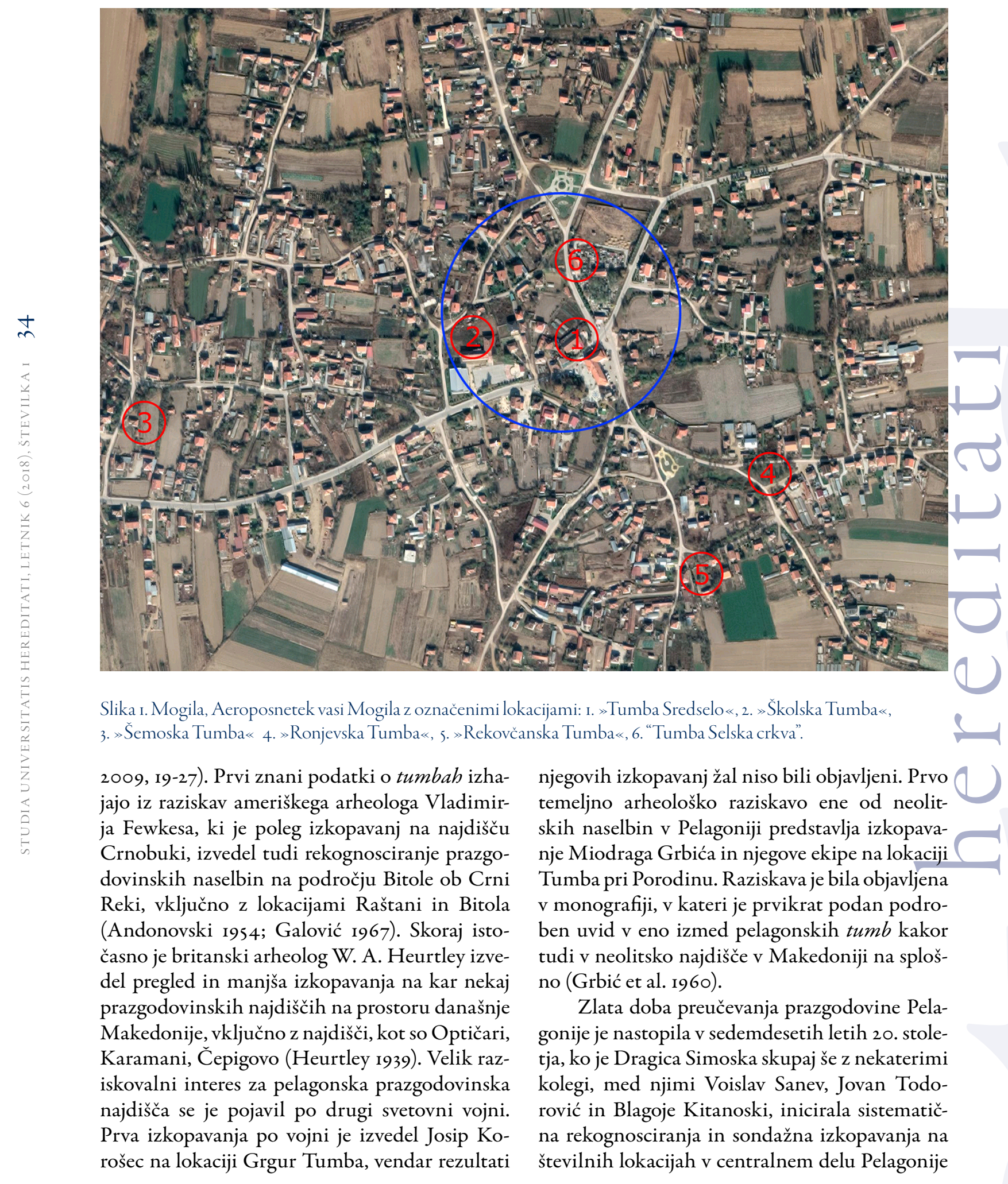


(Simoska in Sanev 1976). Takrat so se vršile sistematične raziskave na najdiščih Veluška Tumba pri Porodinu, Mogila, Optičari, Trn, Karamani, Dobromiri, Radobor in drugje (Simoska in Sanev 1975; Simoska et al. 1976; Simoska in Sanev 1977; Simoska et al. 1979; Simoska 1986; Simoska 1988; Simoska in Kuzman 1990; Simoska 1996b). V prilepskem delu Pelagonije je na najdiščih Slavej, Topolčani in Pešterica raziskoval Blagoje Kitanoski, kar sta kasneje nadaljevala Aleksandar Mitkoski in Duško Temelkoski (Kitanoski 1977; Kitanoski et al. 1978; Kitanoski et al. 1980; Kitanoski et al. 1983; Kitanoski 1989; Kitanoski et al. 1990). Raziskave pa so se izvajale tudi na najdiščih, katera ne moremo označiti kot tumbe (Temelkoski in Mitkoski 200I; Mitkoski 2005; Temelkoski in Mitkoski 2006; Temelkoski in Mitkoski 2008).

Intenzivne arheološke raziskave $\mathrm{v}$ 70-ih letih 20. stoletja so omogočile definiranje značilnosti t.i. pelagonskega neolitika, kar je kasneje v kulturno-zgodovinski maniri privedlo tudi do kulturne opredelitve t.i. veluško - porodinske kulturne skupine. Značilna, bogato okrašena belo slikana lončenina in avtentični antropomorfni modeli hiš so to skupino naredili regionalno prepoznavno in jo izdvojili kot specifično celoto, ki se je neodvisno razvijala tekom celotnega neolitika (Naumov 2010). Po obdobju intenzivnega dela Dragice Simoske in Blagoje Kitanoskega v 70-ih letih 20. stoletja, je zanimanje za neolitska najdišča Pelagonije vse do drugega desetletja 21. stoletja nekoliko zamrlo. Šele tedaj Pelagonija kot specifičen arheološki fenomen ponovno postane središče zanimanja širše strokovne javnosti. Tako so bile manjše arheološke raziskave izvedene na lokaciji Veluška Tumba, katerih rezultati še niso publicirani, v sodelovanju s Poljsko akademijo znanosti pa so bili izvedeni rekognosciranje, topografske meritve in geofizikalno skeniranje na lokacijah Dobromiri, Trn in Mogila (Naumov et al. 2014, 345-372). Rezultati teh raziskav so ponudili nova spoznanja o naselbinskem karakterju tumb, ugotovljena je bila koncentrična razporeditev hiš okoli osrednje zgradbe naselja kakor tudi prisotnost obo- dnega jarka (Naumov et al. 201 4, 345-372). Novo obdobje raziskav kakor tudi presenetljivi rezultati so še dodatno stopnjevali interes za raziskave neolitika na tem področju, kakor tudi namero, $\mathrm{da}$ se $\mathrm{k}$ raziskavam pristopi interdisciplinarno. $\mathrm{V}$ luči tega je bilo vzpostavljeno sodelovanje $s$ paleobotaničnim laboratorijem na Karlovi univerzi in Univerzo Južne Bohemije $\mathrm{z}$ namenom, da se pridobi uvid v neolitsko vegetacijo, klimo in geologijo območja (Naumov 20ı6a). Istočasno so se začela tudi ekstenzivna rekognosciranja, modeliranje in kalibriranje obstoječih radiokarbonskih datacij ter geodetsko mapiranje in GIS modeliranje lokacij tumb v centralni Pelagoniji. Enako pomembno je bilo tudi definiranje časovnega sosledja njihovega nastanka (Naumov in Stojkoski 2015, 169-183; Naumov 2016b).

Eden od rezultatov je tudi izvedba testnega sondiranja na lokaciji Školska Tumba, v osrednjem delu neolitske naselbine $\mathrm{v}$ vasi Mogila. Čeprav so bile raziskave po obsegu skromne, velikosti vsega $4 \times 4 \mathrm{~m}$, pa so prinesle povsem nova spoznanja o neolitskem obdobju Pelagonije in na novo revidirale stratigrafijo in materialno kulturo najdišča, ki je bilo že dlje časa poznano v strokovni literaturi (Simoska et al. 1979). Spričo obsežnosti odkritega arheološkega gradiva $\mathrm{v}$ nadaljevanju predstavljamo samo najbolj izpovedne rezultate.

\section{Kratka zgodovina raziskav neolitske naselbine v Mogili}

Vas Mogila se nahaja v centralnem delu Pelagonije, približno deset kilometrov severno od Bitole. Neolitska poselitev v Mogili je bila prvič evidentirana ob arheološkem rekognosciranju po drugi svetovni vojni (Simoska in Sanev 1976). Takrat se je delno registriral njen obseg, kasneje pa, ko je nastajala »Arheološka karta na Makedonija «, se je definiral tudi njen končen obseg (Simoska 1996a, 36). Glede na arheološko karto je v vasi registriranih 8 neolitskih mikro-lokacij: Tumba Sredselo, Školska Tumba, Šemoska Tumba, Ronjevska Tumba, Rekovčanska Tumba, Tumba Selska crkva, Tumba Trnska-Mogilska idr. (slika I). Šest od njih se nahaja v sami vasi, 
tako, da je težko definirati ali so v prazgodovini le-te delovale ločeno ali ne. Glede na značilnosti ostalih neolitskih lokacij v Pelagoniji, je zelo verjetno, da ta območja predstavljajo le posamezne dele ene velike naselbine, katera je bila vsled časa razčlenjena in pozidana $\mathrm{z}$ manjšimi gradnjami, ulicami, javnimi zgradbami in privatnimi hišami v vasi (Naumov et al. 2014, 345-372). Ravno tako ne gre izključiti možnost, da so $k$ veliki centralni naselbini sinhrono ali v kasnejših prazgodovinskih obdobjih gravitirala tudi manjša naselja - tumbe, kot je to primer pri Optičarih in Trnu (Naumov in Stojkoski 2015, I69-183; Naumov 2016).

Prva izkopavanja na področju Mogile so bila izvedena v letu 1975 na Tumbi Sredselo, leta I977 pa so sondirali še na lokaciji Školska Tumba (Todorović et al. 1980; Simoska 1996a, 36). Tekom leta 1980 je bila izpeljana še ena izkopavalna kampanja, ki se je osredotočila na srednjeveške sloje in pokope (Veljanovska 1996/97). Najnovejše raziskave v tem delu Pelagonije je v letu 2013 izvedla makedonsko-poljska ekipa, ki je na več različnih lokacijah v okolici Mogile izvedla geofizikalna skeniranja (Naumov et al. 2014, 345372), arheološko sondiranje pa je na periferiji lokacije Školska Tumba v letu 2014 izvedla makedonsko - slovenska ekipa. Sondažna raziskava je bila usmerjena $\mathrm{v}$ prepoznavanje stratifikacije naselbine, katere rezultati bodo podrobneje prikazani v nadaljevanju. V letu 2015 je makedonsko-češka raziskovalna ekipa izvedla še paleobotanična sondiranja in GIS modeliranje neolitskih naselij oz. tumb na širšem prostoru centralne Pelagonije (Naumov in Stojkoski 2015, 169-183; Naumov 2016).

Čeprav je bilo nekaj malega o neolitski naselbini v Mogili znanega že pred tem, so šele arheološke raziskave v 70-ih letih 20. stoletja podale temeljna spoznanja o sami naselbini, kar so na nek način potrdile tudi raziskave v letu 20I4, zato jih želimo na tem mestu tudi nadrobneje prikazati. Za našo raziskavo so bila posebnega pomena predvsem izkopavanja, izpeljana v letu I975 pod vodstvom Dragice Simoske, ki so se osredotočila na prazgodovinsko lokacijo Tum- ba Sredselo, na predelu Mogile, kjer je sama mikrolokacija tudi najvišja. Ob tej priliki je bila evidentirana celotna stratifikacija odloženih plasti na prostoru izgradnje sedanje zdravniške ambulante, nedaleč od lokacije sondiranja v letu 2014. Tekom raziskav je bilo tedaj ugotovljeno, da je debelina kulturnega sloja na tem mestu 6,05 $\mathrm{m}$ (Simoska et al. 1979, 9-30), kar je predstavljalo eno najvišjih stratifikacij neolitske naselbine $\mathrm{v}$ Pelagoniji na sploh. Odložene plasti in ostaline so bile tedaj umeščene $\mathrm{v}$ tri neolitske faze in pa ločeno v srednji vek. Najstarejša faza naselbine naj bi pripadala zgodnje neolitski poselitvi Pelagonije, saj so bile v njenih plasteh odkrite arheološke ostaline in materialna kultura, ki je značilna za ta čas, med njimi monohromna in belo slikana keramika, kamniti artefakti, žrtveniki ipd. Kamnita orodja so bila maloštevilna, medtem ko se je keramično posodje ohranilo v obilici. Evidentirane so bile različne oblike posod kot so npr. kroglaste, polkroglaste, konične in bikonične posode $\mathrm{z}$ različnimi dekorativnimi motivi, od barbotina, belo slikanimi linijskimi črtami in sigmami do posod s črno obarvanim ustjem (Simoska et al. 1979, 9-30). Tudi naslednja, nekoliko mlajša faza je vsebovala karakteristične neolitske elemente, pri tem, da je bilo številčnejše kamnito orodje, pestrejši pa je bil tudi ornamentalni izraz na posodju. Odkrite so bile tudi figurine in antropomorfni modeli hiš. Posodje, ki je bilo oblikovno sicer podobno predhodnim oblikam, je okrašeno z arkadnim barbotinom, vertikalnimi plastičnimi rebri, bradavicami ter z belimi slikanimi izdolženimi trikotniki, romboidi ter širokimi in krožnimi trakovi. Najmlajša neolitska faza je bila v precejšnji meri poškodovana s srednjeveškimi jamami in grobovi, zato je bilo njen nastanek časovno težko opredeliti. V njej so se $\mathrm{v}$ enaki meri nahajale srednjeveške kot neolitske najdbe, pa tudi takšne, ki bi jih lahko pripisali kasnejšim prazgodovinskim obdobjem (Simoska et al. 1979, 9-30).

Podobna stratigrafska sekvenca in višina odloženih plasti in ostalin je bila evidentirana tudi na lokaciji Školska Tumba, ki se nahaja v neposredni bližini lokacije Tumba Sredselo (Todoro- 
vić et al. 1980). Iz tega lahko sklepamo, da ti dve lokaciji morda predstavljata le del ene same večje naselbine, katera je bila v kasnejših obdobjih prepolovljena $\mathrm{z}$ recentno cesto in zgradbami. V letu I988 je bila v neposredni okolici Školske Tumbe odkrita in raziskana srednjeveška nekropola (Veljanovska 1996/97). Rezultati teh raziskav, kakor tudi tistih iz 70-ih let 20. stoletja, potrjujejo uporabo lokacije kot prostor pokopavanja. Že v 70-ih let 20. stoletja je bilo odkrito večje število grobov, datiranih v širok časovni razpon od 6 . do i9. stoletja. Zgodnejši izmed grobov naj bi bili povezani z vpadi Gotov v Pelagonijo, kar je potrjeno tudi s pomočjo materialne kulture.

Po petindvajsetletnem raziskovalnem premoru, se je $\mathrm{v}$ letu 2013 ponovno pristopilo $\mathrm{k} \mathrm{raz}$ iskavam tumb v okolici Mogile z uporabo novih arheoloških metod in tehnologij. Makedonsko-poljska ekipa je izpeljala geofizikalno skeniranje na lokacijah Tumba Sredselo in Ronjevska Tumba, ki so potrdile obstoj podzemnih objektov in krožno organiziranih jam (Naumov et al. 20I4, 345-372), v letu 2015 pa je makedonsko-češka ekipa vršila vzorčenje s pomočjo vrtin na prostoru med lokacijama Ronjevska Tumba in Tumba Sredselo (Naumov 2016a). Rezultati vrtanja so pokazali, da se je ohranila znatna količina peloda tudi v kulturnih slojih izven gabaritov naselja tumbe. $Z$ ozirom na globino odkritih keramičnih najdb pa se lahko predpostavi tudi domneva, da se je na obeh lokacijah življenje odvijalo tudi izven naselja, kar pomeni, da je prostor aktivnosti teh prazgodovinskih skupnosti obsegal bistveno večje območje, kot se je predvidevalo do sedaj (Naumov 2016a). Istega leta se je izvedlo tudi detajlno rekognosciranje Pelagonije, pri čemer so bila odkrita številna nova najdišča, hkrati pa so bile potrjene in natančneje locirane tudi nekatere od že poznanih lokacij tumb (Naumov in Stojkoski 2015, 169-183; Naumov 2016a). $\mathrm{V}$ teh raziskavah, katerih cilj je bil opredeliti gostoto prazgodovinskih naselij tumb s pomočjo GIS modeliranja, je bil zaobjet celoten areal današnje vasi Mogila. Rezultati so pokazali, da prostor Mogile skupaj s tistim na lokacijah Ribarci, Trn in Optičari, predstavlja enega izmed najgosteje naseljenih območij v prazgodovini, ko centralna naselja oz. tumbe dosegajo skupno površino tudi do $8000 \mathrm{~m}^{2}$. Okoli njih so se formirala manjša naselja, za katera pa bo mogoče šele s prihodnjimi raziskavami potrditi ali ovreči predpostavko časovne pripadnosti in sicer, ali so bile sinhrone s centralno naselbino oziroma ali so nastale v drugih prazgodovinskih obdobjih.

Vsi dosedanji rezultati raziskav kažejo na to, da je območje, ki ga zajema vas Mogila igral ključno vlogo v neolitiku Pelagonije in predstavlja enega od centrov prvih kmetovalskih skupnosti na tem prostoru. To so potrdila tudi ponovna arheološka sondiranja makedonsko-slovenske ekipe v letu 20r4. Poleg tega, da smo z rezultati sondiranj potrdili številna predhodna spoznanja, smo uspeli pridobiti tudi povsem nove podatke o načinu formiranja neolitskih tumb, kakor tudi o razvoju neolitskih in srednjeveških skupnosti na tem prostoru.

\section{Izkopavanje na lokaciji Školska Tumba v letu 2014}

Po daljšem raziskovalnem premoru so se v letu 2014 na najdišču Mogila vršile arheološke raziskave v obliki sondiranja, katere sta vodila $\mathrm{dr}$. Goce Naumov (Muzej na Makedonija) in doc. dr. Alenka Tomaž (Univerza na Primorskem, Fakulteta za humanistične študije, Inštitut za arheologijo in dediščino). Raziskave so se osredotočile na zahodno periferijo lokacije Školska Tumba, ki se nahaja v centralnemu delu vasi, na katerem stoji osnovna šola "Goce Delčev" ter nekaj stavb, ki se nahajajo vzdolž treh ulic (slika 2). Ta del neolitske naselbine je bil v novejših obdobjih v veliki meri poškodovan z gradbenimi posegi, tako da mikrolokacija daje vtis, kot da je od osrednjega centralnega dela naselja nekoliko oddvojena. Spričo podobnosti v arheološkem gradivu obeh lokacij, bi lahko sklepali, da sta obe le del ene večje naselbine, saj odražata obeležja, značilna za večja naselja v Pelagoniji. Bodoče raziskave bodo to domnevo lahko še dodatno utemeljile, že tiste iz leta 2014 pa kažejo številne argumente temu v prid. 


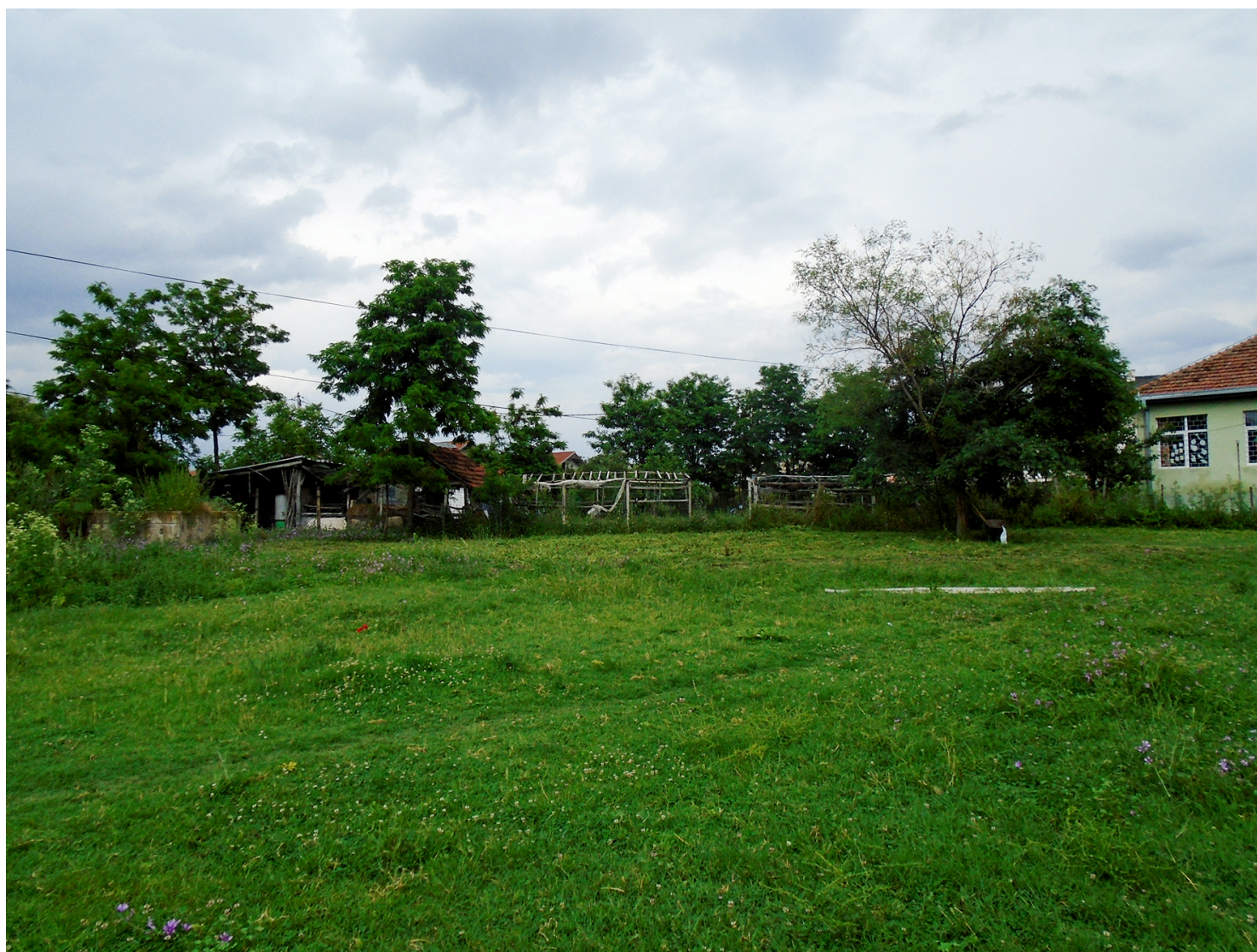

Slika 2. Mogila, pogled na mikrolokacijo arheološkega testnega sondiranja (Školska Tumba), na dvorišču osnovne šole »Goce Delčev« (foto: Goce Naumov, arhiv UP FHŠ IAD).

Pri arheološki raziskavi (tako pri samih terenskih raziskavah kakor tudi pri dokumentiranju arheološkega gradiva) so sodelovali tudi drugi arheologi in študentje iz obeh držav Makedonije in Slovenije. Arheološko sondiranje je potekalo na prostoru dvorišča osnovne šole "Goce Delčev" v velikosti 4,0 x 4,0 m v juniju in juliju leta 20r4. Pred samim posegom je bil prostor raziskave zatravljen, na sami lokaciji pa ni bilo vidnih recentnih poškodovanj ali preoblikovanj terena. Pogoji za izvedbo terenskega dela so bili optimalni. Metodologija arheološkega testnega sondiranja je temeljila na stratigrafskemu odstranjevanju sosledja odloženih plasti in arheoloških ostalin, ki so bile dokumentirane kot samostojne stratigrafske enote. Grajene arheološke ostaline (mlajših obdobij) so se ohranjale $\gg$ in situ «, odstranjevala se je le zemljina. Za dokumentiranje arheološke stratifikacije je bila poleg klasične opisne dokumentacije uporabljena tudi klasična foto-dokumentacija, ki je bila izdelana s pomočjo A - stativa (slika 3), kar pomeni, da je bila fotografija izdelana vedno iz iste pozicije, kar je omogočilo boljšo primerljivost fotodokumentacije. Vse arheološke ostaline so bile v celoti georeferencirane v Gauss-Krügerjevem sistemu, kar pome$\mathrm{ni}$, da so jim bile določene $\mathrm{x}, \mathrm{y}$ in $\mathrm{z}$ koordinate $\mathrm{v}$ absolutnem geodetskem sistemu (slika 4), digitalno izrisane ter fotografsko dokumentirane z vertikalno fotografijo, kar je omogočilo tudi natančen izris načrta posameznih faz naselbine. 


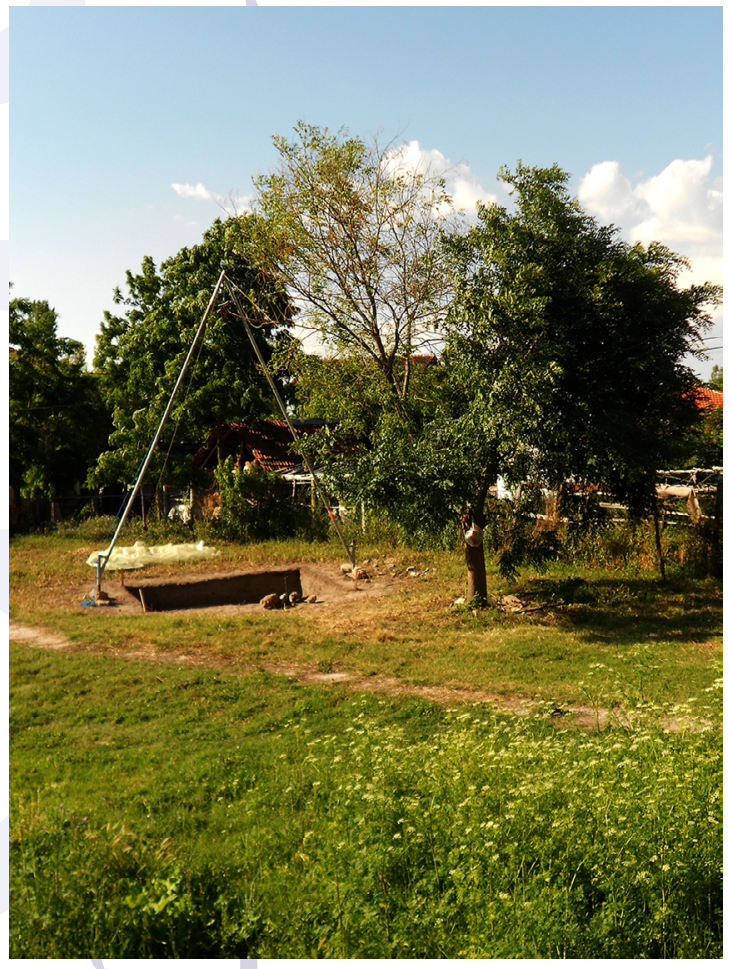

Slika 3. Mogila, pogled arheološko testno sondo z instaliranim fotografskim A-stativom (foto: Aleš Ogorelec, arhiv UP FHŠ IAD).

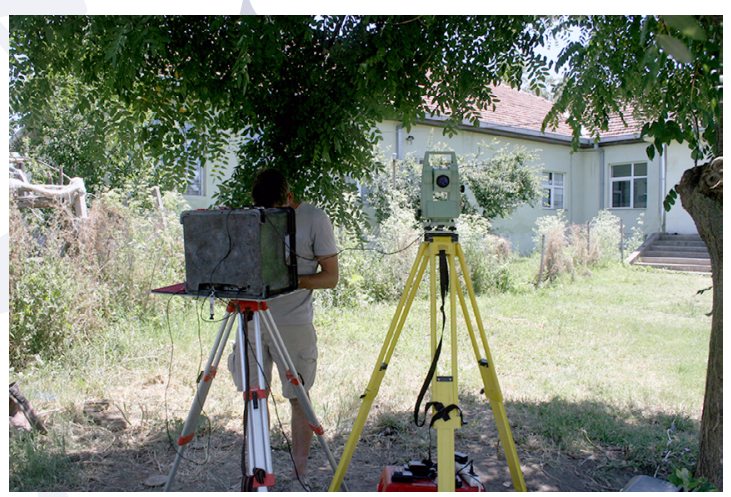

Slika 4. Mogila, delo na terenu (georeferenciranje arheoloških ostalin) - merjenje s totalno postajo (foto: Aleš Ogorelec, arhiv UP FHŠ IAD).

\section{Stratigrafija}

Stratifikacija plasti in arheoloških ostalin je v raziskani sondi obsegala razpon od geološke osnove do povsem recentnih ostankov v skupni debelini 2,90 m. Ugotovljena debelina kulturne plasti je sicer dosti manjša od tiste, dokumentirane z izkopavanji leta 1977 (6,09 m). Takšna razlika v debelini pa niti ne preseneča, saj so izkopavanja v letu 1977 potekala na najvišjem prostoru tumbe, medtem ko so raziskave v letu 2014 zaobjele le prostor njene periferije. Pri tem je potrebno poudariti še, da so recentni gradbeni posegi in pa srednjeveške jame v večji meri poškodovali večino evidentiranih neolitskih plasti in ostalin. Vsem okoliščinam navkljub pa je stratigrafija omogočila vpogled $\mathrm{v}$ jasno zamejene arheološke kontekste, obseg materialne kulture pa je opredelil karakter te izjemno zanimive naselbine.

Rezultati izkopavanj potrjujejo jasno sosledje štirih poselitvenih faz (horizontov), v katerih so bile evidentirane številne stratigrafske enote, ki označujejo arheološke kontekste različnih ostalin objektov in plasti. Pri njihovem odstranjevanju in dokumentiranju so bila upoštevana vsa načela arheološke stratigrafije $\mathrm{z}$ uporabo Harrisove matrike, kar je omogočilo precizno lociranje odkritih arheoloških kontekstov kakor tudi jasen uvid v samo stratigrafijo naselbine. $\mathrm{Na}$ ta način pridobljeni podatki podajajo lažje berljiv in primerljiv pregled arheološke dokumentacije odkritih kontekstov, vsaj v tistem delu območja, kjer ni bilo kasnejših posegov.

Štiri poselitvene faze so bile najjasneje izražene v severno-zahodnem profilu, kjer so srednjeveški in recentni posegi le v manjši meri poškodovali spodaj ležeče plasti (slika 5).

Najstarejša (I.) poselitvena faza je obsegala neolitske plasti in arheološke kontekste, ki so se odložili tik nad naravno geološko osnovo. Odkriti arheološki konteksti so bili tu ohranjeni najbolje, čeprav so tudi tu plasti vsaj še delno poškodovane s srednjeveškimi jamami. V prvi poselitveni fazi je bilo evidentiranih več arhitekturnih ostalin, nekaj neolitskih jam kakor tudi plasti, ki jih lahko povezujemo z naravnimi geološkimi procesi, ki so se odvijali v najzgodnejših fazah naselbine. Najnižja plast prve poselitvene faze je bila sestavljena iz mivkastega peska, $\mathrm{v}$ katero so bile vkopane posamezne zgodnje neolitske jame. V njih so bili odloženi posamezni 


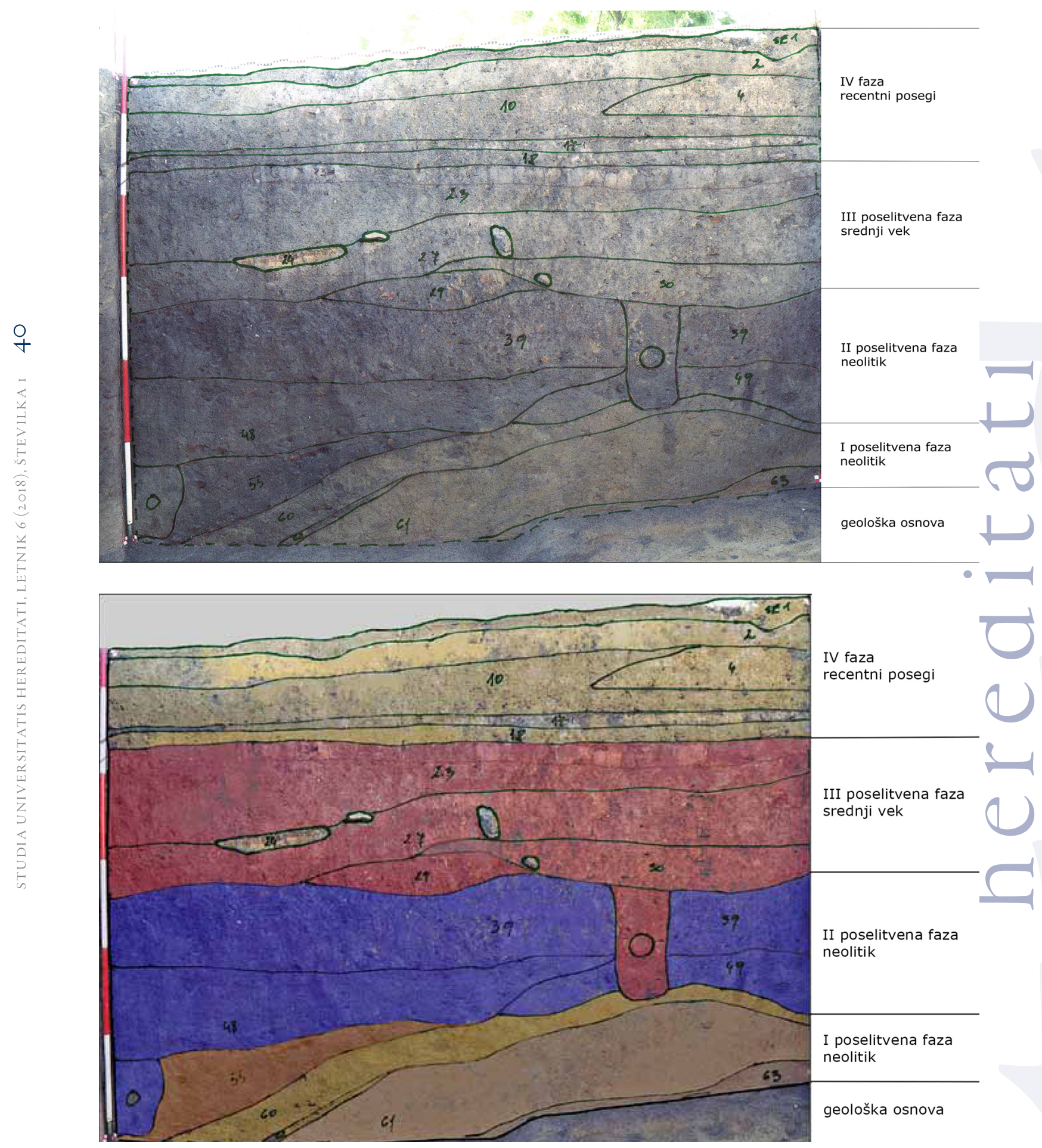

Slika 5. Mogila, stratifikacija plastiv $S$ profilu, oznake stratigrafskih enot ter faziranje stratigrafije (izdelali: Alenka Tomaž, Goce Naumov in Aleš Ogorelec, arhiv UP FHŠ IAD). 
odlomki fine lončenine, odlomek modela hiše, noga žrtvenika, sekira in žrmlje. Zunaj teh jam, takoj nad geološko osnovo, pa so bili odloženi odlomki fine polirane in belo slikane keramike, kamnita orodja, sekire, keramični projektili za frače, perforirani keramični diski, keramične figurine in obdelan jelenov rog, kar jasno opredeljuje neolitski karakter te poselitvene faze. Nad njo so bile odkrite arhitekturne ostaline, ki v neolitiku Pelagonije predstavljajo novost. Izkazovale so se kot ostanki polkrožne zgradbe (objekta), zgrajene iz tanjših lesenih kolov (evidentirani kot vkopi za količe). Na območju sonde so bile sicer odkrite samo ostaline polovice zgradbe (druga polovica je segla izven izkopnega polja). Notranjost objekta je bila poškodovana z nekaj manjšimi jamami. Zgradba je bila postavljena na umetno izravnan prostor, kateri se je na vzhodnem delu naglo spuščal. Na tem predelu je bila odkrita koncentracija nekoliko masivnejših kolov, kateri bi lahko delovali kot nosilci za leseno platformo. Spričo dosedanjih podatkov je nemogoče potrditi, da sta ti dve konstrukciji medsebojno povezani, čeprav, glede na njuno bližino, takšne možnosti ne gre izključiti. $\mathrm{Na}$ mestu, kjer teren naglo pada, je za to fazo značilno sosledje temnejših tankih plasti. Te so rezultat delovanja (dviganja in padanja) vodne gladine, kar kaže na številne poplavne dogodke, ki so značilni za Pelagonijo še danes. Takšni procesi premeščajo zemljo in v njej odložene najdbe, zaradi česar se formirajo zelo tanke in lečasto odložene naplavinske plasti. Zraven njih se je nahajala najnižja izkopna točka v sondi, kjer je bilo zaznano tudi poniranje vode iz geološke osnove. Glede na geološke značilnosti Pelagonije in tudi same lokacije tumbe je bilo zaznano, da samo geološko osnovo terena sestavlja vodni peskovit oz. mivkast sediment, ki je verjetno nastal kot posledica morskega delovanja na prostoru Pelagonije pred nekaj milijoni let. Samo dno sonde pa je nedvomno pokazalo, da so bila naselja prvih poljedelcev v Pelagoniji, t.i. tumbe, formirane na naravno privzdignjenih terasah iznad zamočvirjenih območij.
Drugo poselitveno fazo lahko ravno tako pripišemo neolitskemu obdobju, čeravno je zanjo značilno, da je bila precej poškodovana s srednjeveškimi jamami; precej poškodovana pa je tudi njena zgornja površina, na kateri se pojavljajo še dokaj številni srednjeveški odlomki. V drugi poselitveni fazi je bila odkrita posoda, ki je značilna za četrto fazo veluško-porodinske kulturne skupine, pa projektili za fračo, in še drugi odlomki neolitskih posod (slika 5). Lahko jo razumemo kot najmlajši arheološki kontekst z jasnimi neolitskimi obeležji, ki je bil odkrit na prostoru raziskav. Poleg že omenjenih najdb, pa so bili v drugi poselitveni fazi odkriti tudi številni drugi neolitski artefakti, večinoma premešani po plasteh. Med njimi so bila razmeroma številna kamnita orodja, odlomki keramičnega posodja, tipičnega za faze 2.-4. veluško-porodinske kulturne skupine, kakor tudi deli antropomorfnih modelov hiš, figurine, projektili za fračo, ploščati diski s perforacijo idr.

Nad njo se je nahajala tretja poselitvena faza, katero na osnovi arheoloških najdb časovno lahko uvrstimo v srednji vek (slika 5). V plasteh te faze so bili sicer evidentirani tudi odlomki neolitske keramike, kar dokazuje, da so srednjeveške jame pogosto posegle tudi v neolitske plasti, zaradi česar so se neolitske najdbe sekundarno odložile v višje ležečih srednjeveških kontekstih. Za razliko od predhodnih raziskav pa $\mathrm{v}$ arheološki kampanji v letu 2014 ni bil odkrit niti en srednjeveški pokop. $\mathrm{V}$ tej poselitveni fazi ni bilo evidentiranih niti arhitekturnih ostalin z izjemo nekaj jam in jarkov, kar kaže na to, da ta predel naselbine $\mathrm{v}$ srednjem veku ni bil uporabljan kot prostor za bivanje ampak kot prostor gospodarskih aktivnosti. Mnoštvo odkritih srednjeveških pekačev namreč nakazuje, da je bil prostor namenjen pripravi in uživanju jedi, $v$ prvi vrsti kruha (G8). Spričo dejstva, da so bili v predhodnih izkopavanjih odkriti številni skeletni pokopi, bi lahko morda sklepali, da so bili odkriti pekači namenjeni uživanju hrane ob pokopu oz. drugim pogrebnim običajem. Vsekakor pa bi bilo potrebno omenjene hipoteze $\mathrm{v}$ prihodnje preveriti še na drugih lokacijah naselja, morda na naj- 
višji točki tumbe. Tako bi lahko na eni strani preverili deponiranje pekačev $\mathrm{v}$ plasti, na drugi pa prisotnost bivališčc kar bi morda podalo povsem drugi uvid v srednjeveško materialno kulturo tega naselja. Preostale najdbe te poselitvene faze obsegajo še odlomke drugih tipov srednjeveškega posodja (predvsem lonce ipd.), nekateri izmed njih so tudi okrašeni z vrezi. Izstopa morda primerek sklede, okrašene $\mathrm{z}$ antropomorfno upodobitvijo, ki sodi v čas I2. oziroma I3. stoletja (GI). Poleg keramičnih najdb so bili v tej fazi odkriti še odlomki steklenih zapestnic $\left(\mathrm{G}_{4}-5\right)$, deli kovinskih ploščic $\left(G_{2}\right)$, odlomki puščic $\left(G_{7}\right)$, nožev in keramičnih pip (G3). Najdbe izkazujejo časovni razpon od srednjega veka do otomanskega obdobja.

Najmlajša, četrta poselitvena faza se je formirala kot rezultat novejših gradbenih aktivnosti, saj se je v njenih plasteh nahajal odpadni gradbeni material in pa najdbe zadnjih dveh stoletij (slika 5), v njej pa so bile evidentirane še neolitske najdbe kakor tudi srednjeveško keramično posodje.

\section{Arbitekturne ostaline}

Prostor raziskav je bil razmeroma majhen, temu ustrezno pa so bile razmeroma skromne tudi odkrite arhitekture ostaline.

$\mathrm{V}$ srednjeveških naselbinskih fazah ni bilo arhitekturnih ostalin, ki bi kazale na prisotnost bivanjskih objektov ali gospodarskih zgradb. V zgornjih dveh poselitvenih fazah je bil evidentiran jarek, sledi ožgane ilovice in mnogotere vkopane jame, katere pa žal ne podajo mnogo informacij o življenju v srednjem veku. Prisotnost jam sicer potrjuje, da so imele prazgodovinske tumbe $\mathrm{v}$ srednjem veku poleg funerarnega tudi posvetni značaj, saj so lahko bile uporabljane tudi kot prostor odpada. Ostaja pa vprašanje, ali so evidentirane odpadne jame povezane $\mathrm{z}$ obredjem pokopavanja ali pa morda $\mathrm{z}$ naselbino, katere sledi do sedaj še niso bile odkrite. Med srednjeveškimi jamami izstopata dve. $V$ eni od njih je bil pri dnu jame odkrit pokop psa (slika 6a), tik pod njim pa skoraj v celoti ohranjen vrč (slika $6 \mathrm{~b}$ ). V drugi jami je bila odkrita lobanja goveda.
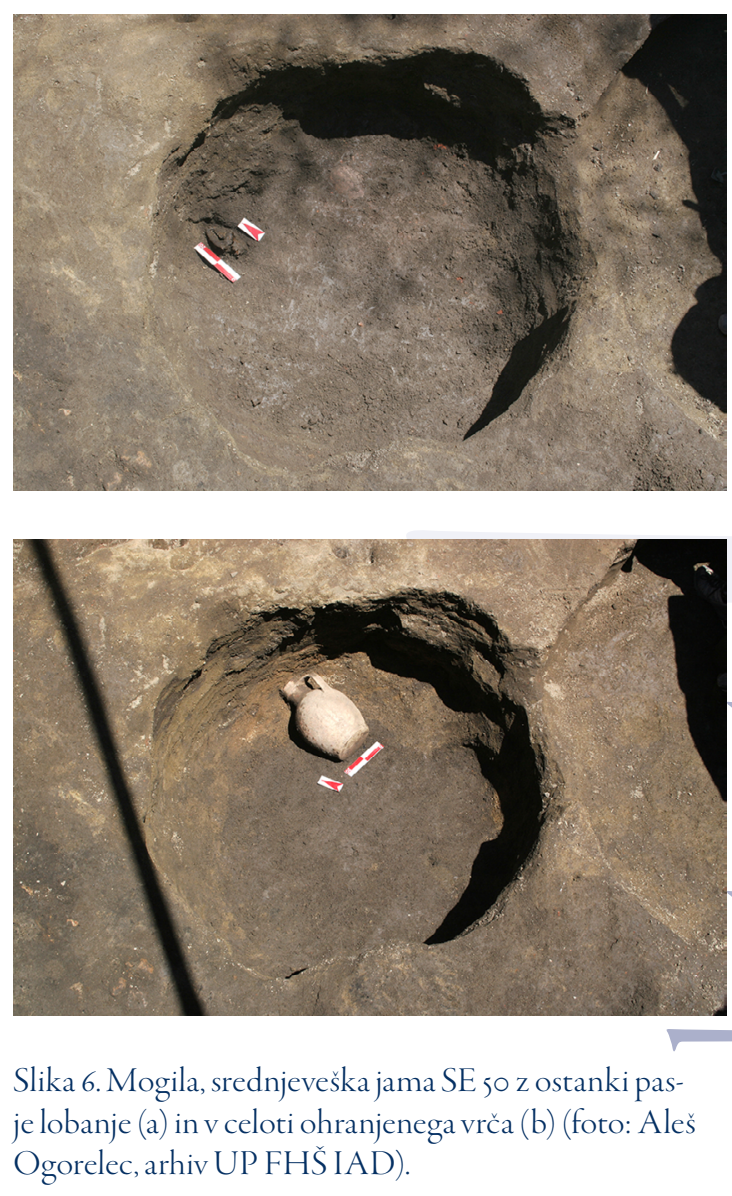

$\mathrm{Na}$ celotnem prostoru Mogile niti v eni od raziskav do sedaj niso bile evidentirane ostaline srednjeveških bivanjskih objektov, zato se tudi ne more potrditi, da je bil prostor v srednjem veku uporabljen kot naselbinski prostor. Takšna odsotnost stavb bi sicer lahko bila planirana, ali pa se tako odraža njihovo uničenje ob izgradnji recentnih bivališč in javnih zgradb. Vsekakor bi bilo smiselno to hipotezo preveriti z raziskavami na najvišji središčni točki naselja. Po drugi drugi strani pa je bilo na več lokacijah evidentirano, $\mathrm{da}$ so se pelagonske prazgodovinske tumbe $\mathrm{v}$ srednjem veku pogosto uporabljale kot prostor pokopavanja, v bližini katerega je bila zgrajena cerkev, zaradi česar se je ustvarilo mnenje, da veljajo za prostor, kateri ni bil namenjen profanim aktivnostim in bivanju. Odprto ostaja tudi vprašanje, v katerem časovnem odseku srednjega veka 

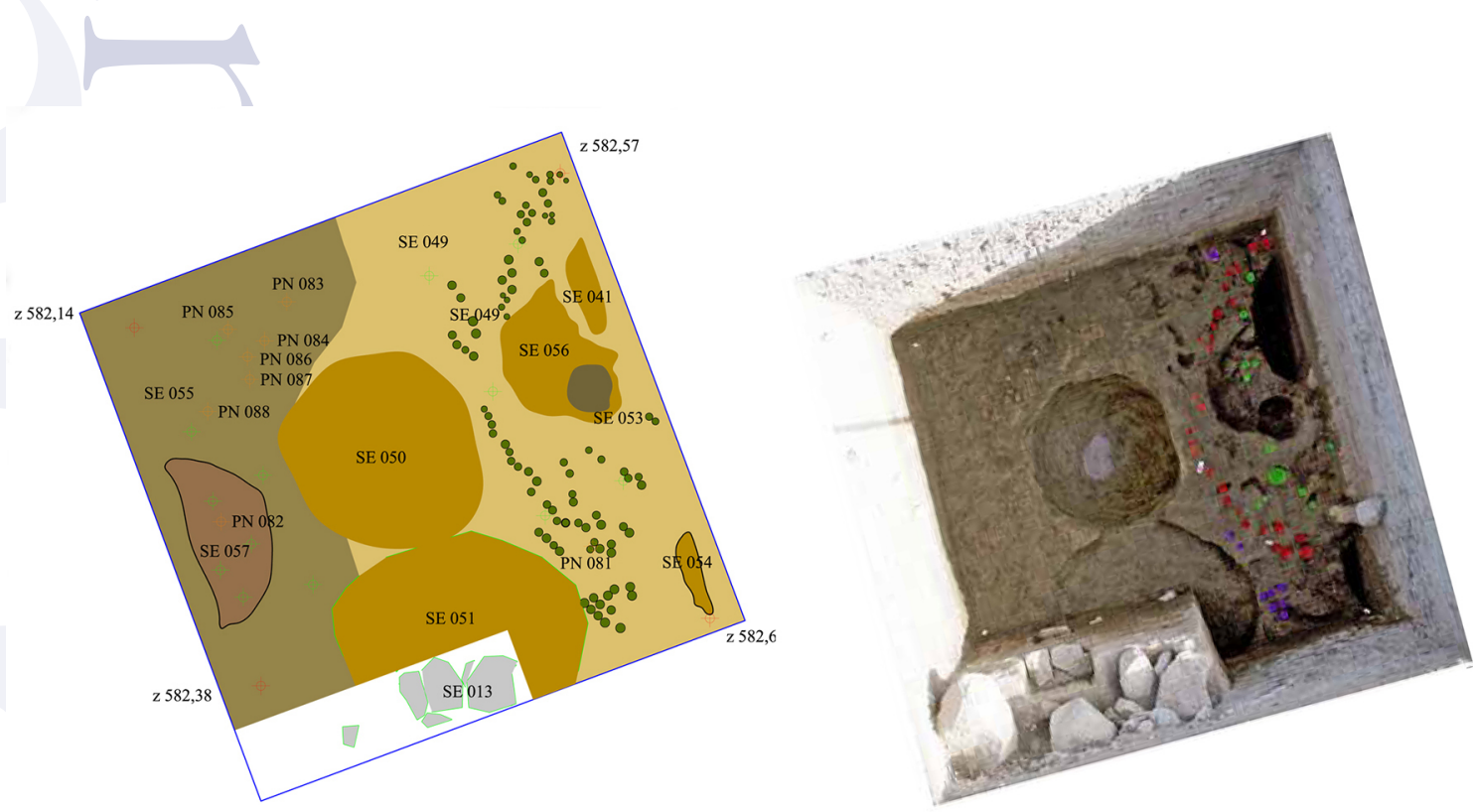

Slika 7. Mogila, izris načrta arhitekturnih ostalin krožnega objekta iz najstarejše neolitske poselitvene faze in pripadajoča fotodokumentacija (izris in foto: Aleš Ogorelec, arhiv UP FHŠ IAD).

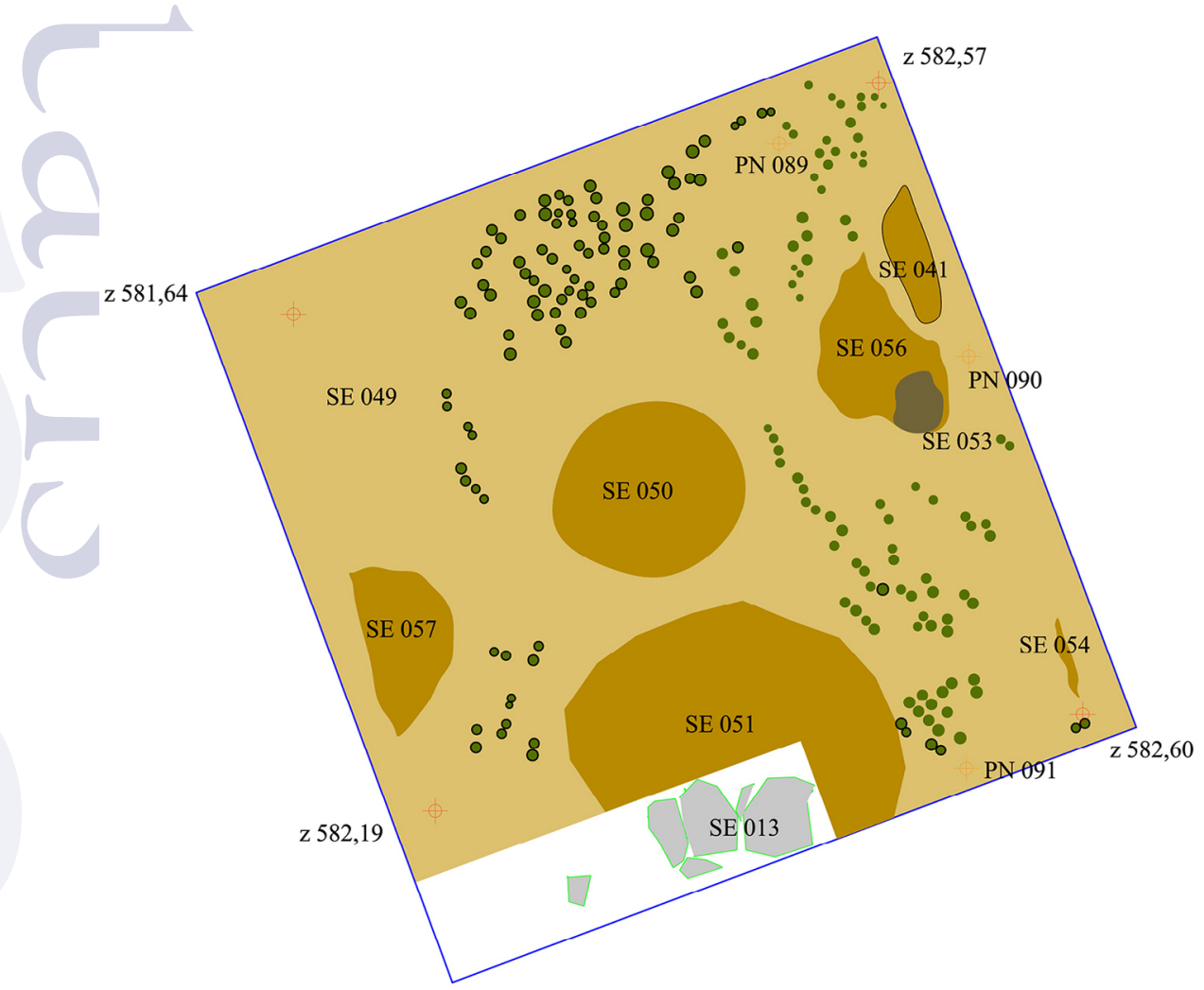

Slika 8. Mogila, izris načrta potencialne lesene platforme in arhitekturnih ostalin krožnega objekta iz najstarejše poselitvene faze (izris: Aleš Ogorelec, arhiv UP FHŠ IAD). 
je imelo naselje takšen status oziroma ali morda ni možno, da bi bili v prihodnje morda lahko odkriti tudi bivanjski objekti iz tega časa.

\section{Neolitske arbitekturne karakteristike}

$\mathrm{V}$ posameznih fazah neolitske poselitve so bile evidentirane arheološke ostaline, ki podajajo nekatere ključne informacije $\mathrm{v}$ zvezi $\mathrm{z}$ neolitskimi arhitekturnimi karakteristikami. Za razliko od srednjeveških plasti, so bili v neolitskih plasteh ugotovljeni nekateri objekti in pa jame, katere je mogoče povezovati z življenjem $v$ naselbini. $V$ najzgodnejši fazi so bile odkrite ostaline polkrožne konstrukcije, sestavljene iz tanjših vkopanih kolov (slika $7 \mathrm{a}, \mathrm{b}$ ), vendar pa v njeni okolici kakor tudi ne v pripadajočih neolitskih plasteh ni bila odkrita večja količina lepa, ki bi lahko nakazovala na kakšno večjo zidano in z glino ometano konstrukcijo. Evidentirana konstrukcija bi morda lahko predstavljala del gospodarske stavbe ali pa del nekakšnega bivanjskega objekta, kateri ni imel standardnih obeležij neolitske arhitekture - gradnja iz lesenega prepleta in ožgane gline lepa (glede na to, da gre za izrazito vodno okolje, morda takšen način gradnje niti ne gre predvidevati). Med raziskavami sta bili registrirani dve fazi gradnje, tako, da je možno, da je bil objekt bodisi popravljen oziroma razširjen (slika $7 \mathrm{~b}$ ). Poudariti je potrebno še, da je bila med dvema koloma na južni strani objekta odkrita kamnita sekira, kar bi lahko bilo rezultat njenega namernega deponiranja v tem delu objekta. Pri tem naj izpostavimo še, da je bila omenjena stavba postavljena na ravnem prostoru, ki je omogočal stabilno statično konstrukcijo, pri čemer nagel padec terena $\mathrm{v}$ neposredni bližini lahko nakazuje na možnost, da je bil teren, na katerem je bil postavljen objekt, namerno zravnan.

$\mathrm{Na}$ prostoru, kjer teren naglo pada, je bila $\mathrm{v}$ nadaljevanju evidentirana večja koncentracija na gosto postavljenih kolov, nekoliko debelejših od tistih, kateri so sestavljali ovalno zgradbo na platoju (slika 8). Lahko bi se predpostavljalo, da so le-ti nosili leseno platformo, za katero pa zaenkrat še ne moremo potrditi, da je bila sočasna z zgradbo na zravnanem platoju. V kolikor bi bili obe stavbi sočasni, obstaja velika verjetnost, da sta bili v medsebojni povezavi, lahko pa da je bila druga stavba zgrajena kot razširitev k ovalni zgradbi. V primeru stavbe $\mathrm{z}$ debelejšimi koli obstaja velika verjetnost, glede na mikrolokacijo in stratifikacijo plasti, da gre za stavbo na koleh. Na žalost je bil odkrit le relativno majhen del konstrukcije, tako, da rekonstrukcija celotne zgradbe žal ni možna, kakor tudi ni možno opredeliti njenega namena. $\mathrm{V}$ vsakem primeru pa je potrebno možnost stavbe na koleh razumeti kot realno na prostoru Pelagonije, spričo pogostih poplav in zamočvirjenosti okoliškega prostora. Tovrstne zgradbe na koleh so se gradile v Mogili tudi še v času po 2. svetovni vojni, zato ne gre izključiti možnost, da so takšne stavbe obstajale tudi pred tem, morda že v neolitskem obdobju. Vsekakor se $\mathrm{v}$ prihodnjih raziskavah ta hipoteza lahko potrdi ali ovrže, čeprav že sedaj razpolagamo s časovno sinhronimi analogijami, da so naselbine, ki so locirane zraven vode, lahko narejene na koleh (Kuzman 2013, 297-430).

Poleg arheoloških ostalin, ki jih lahko povežemo $\mathrm{z}$ nekdanjo arhitekturo, so bile v najstarejši neolitski fazi odkrite tudi nekatere manjše jame. V eni od njih so bili odkriti odlomki fine keramike, kamnita klina ter manjši odlomek keramične »hiše«, za katerega pa se ne da ugotoviti, če pripada varianti $z$ antropomorfnim cilindrom ali kakšni drugi varianti. Glede na to, da je bilo v okolici jam odkritega izjemno malo gradiva, kakor tudi dejstvo, da v ostalih jamah gradiva takorekoč ni, bi lahko sklepali, da so bile zgoraj omenjene najdbe $\mathrm{v}$ jamo odložene namerno. Jama predstavlja najzgodnejšo antropogeno aktivnost na prostoru raziskave; pod njo so se namreč nahajale samo plasti brez arheološkega gradiva oz. geološka osnova.

\section{Arheološke najdbe}

$\mathrm{Na}$ najdišču, majhnim dimenzijam sonde navkljub, so bile odkrite številne drobne arheološke najdbe, ki nam nudijo informacije, vezane na ekonomske in duhovne vidike tako praz-

Najdbe v tekstu so označene s črko $G$, kar označuje gradivo in pa zaporedno številko. Posebej ne navajamo slike, na kateri se nahaja. 

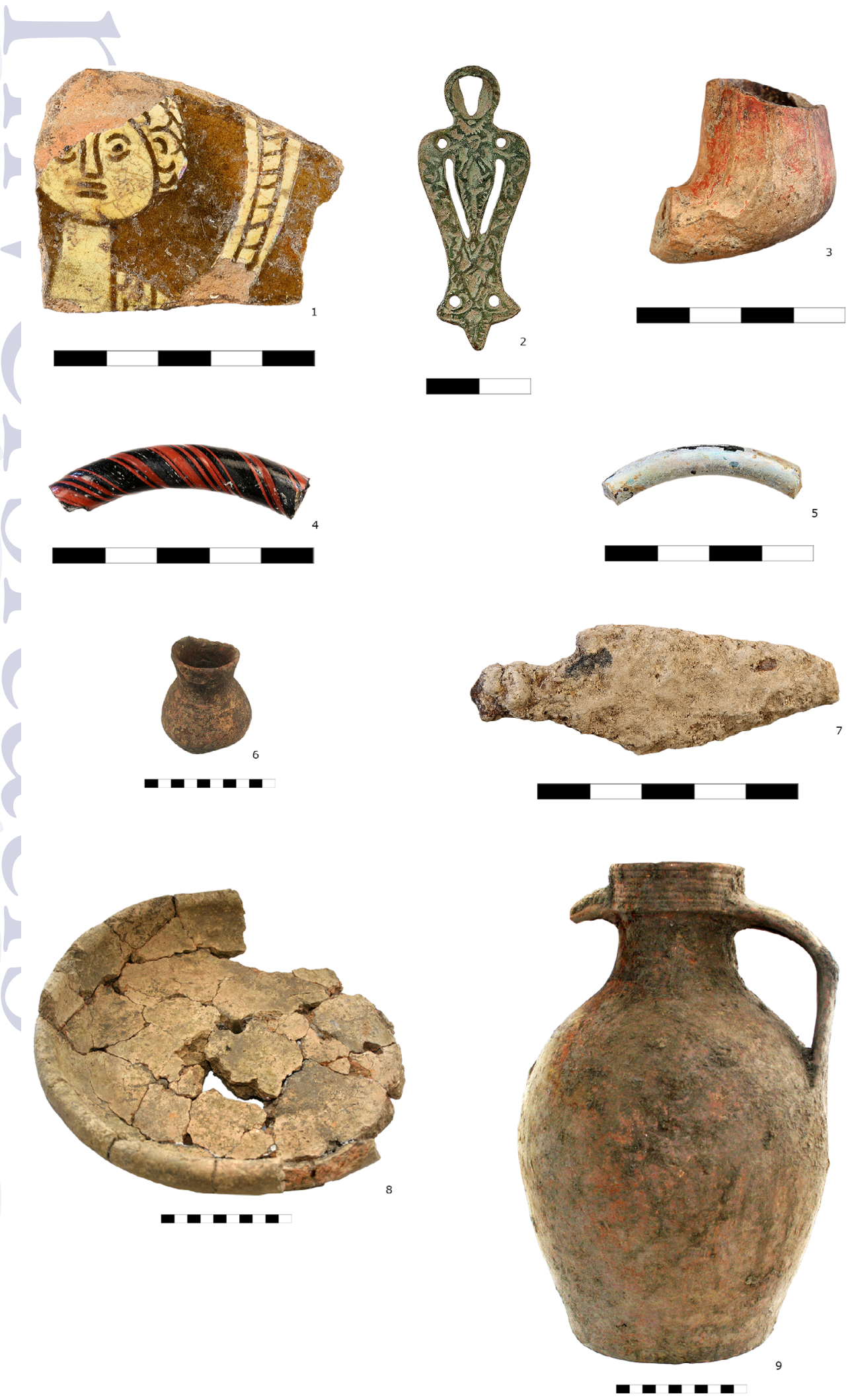


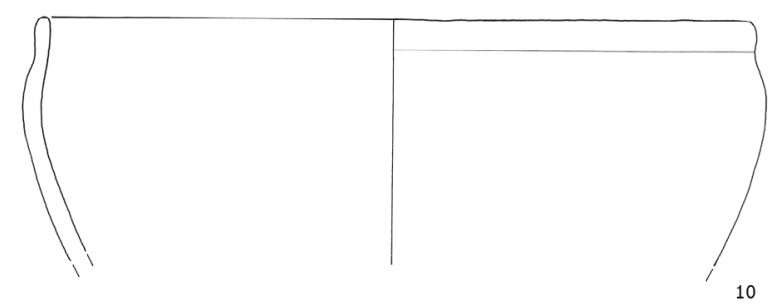

$\stackrel{6}{+}$

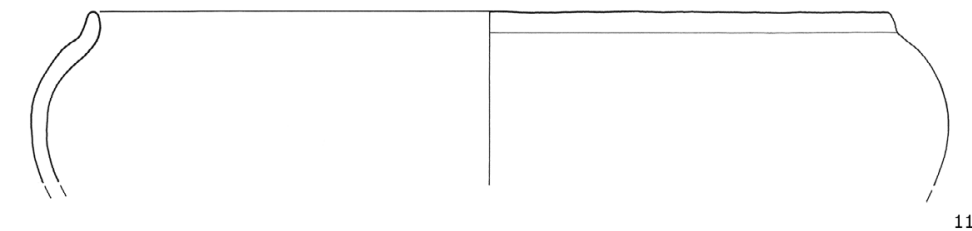

11
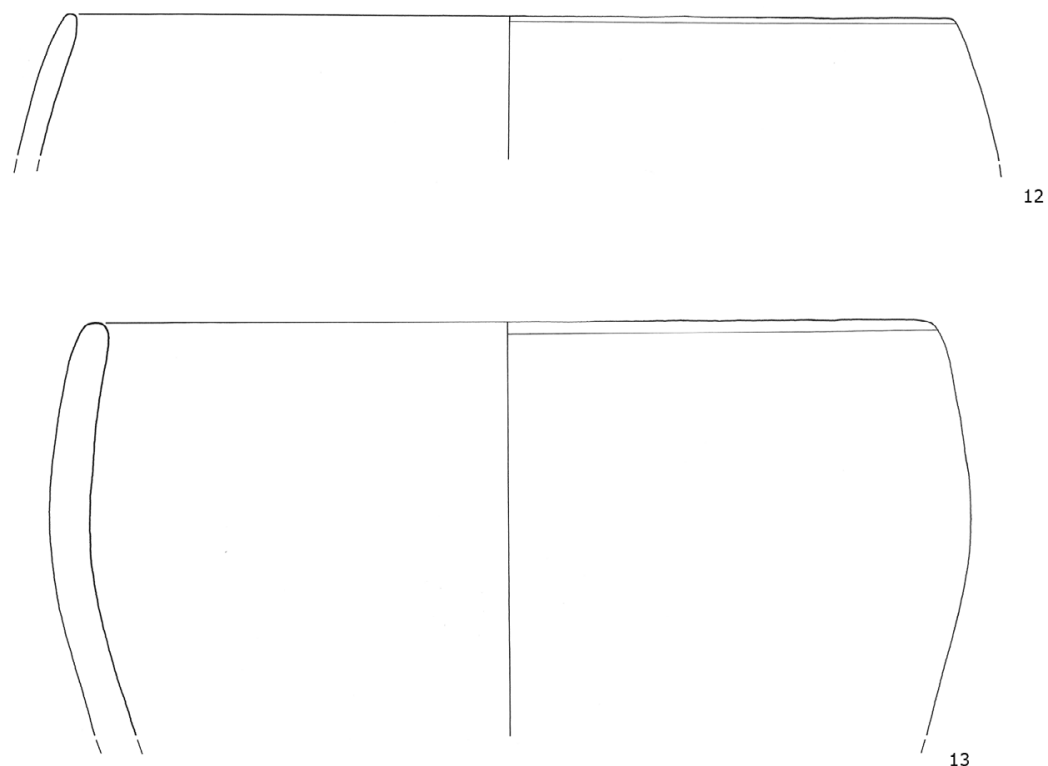

-
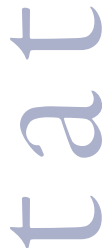

-
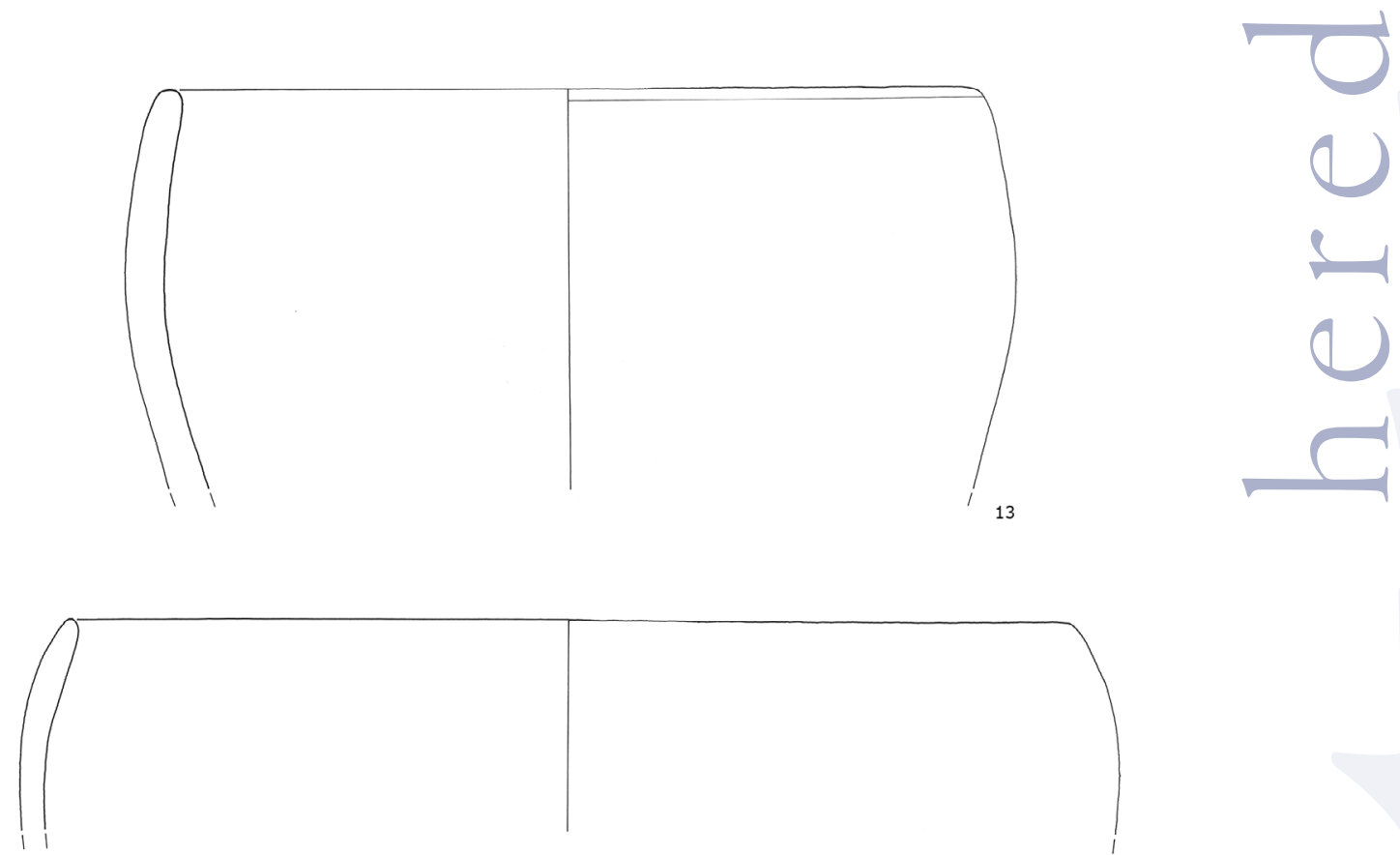

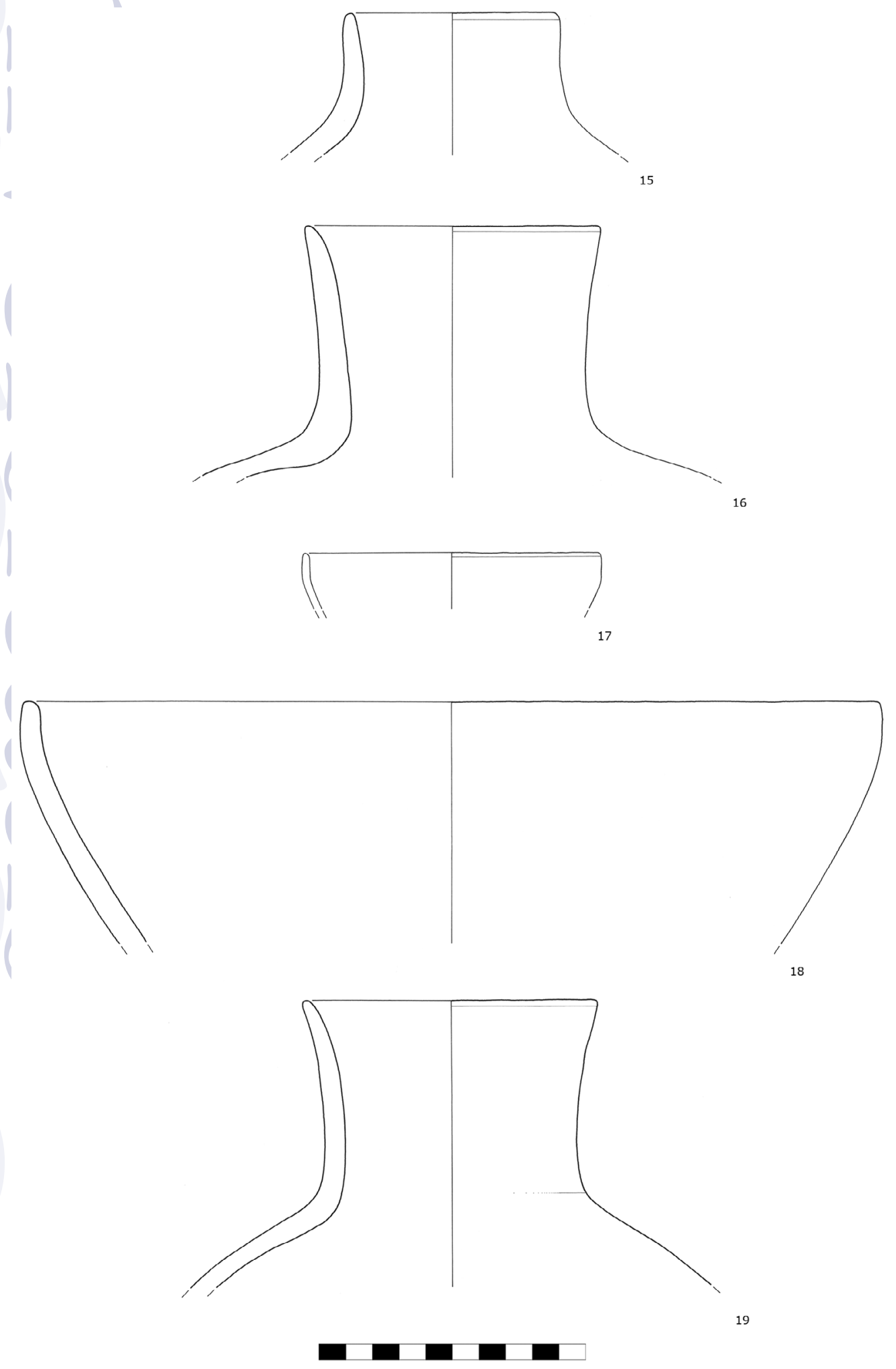


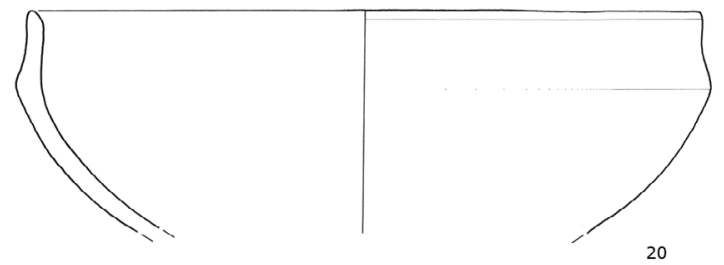

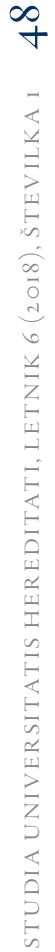
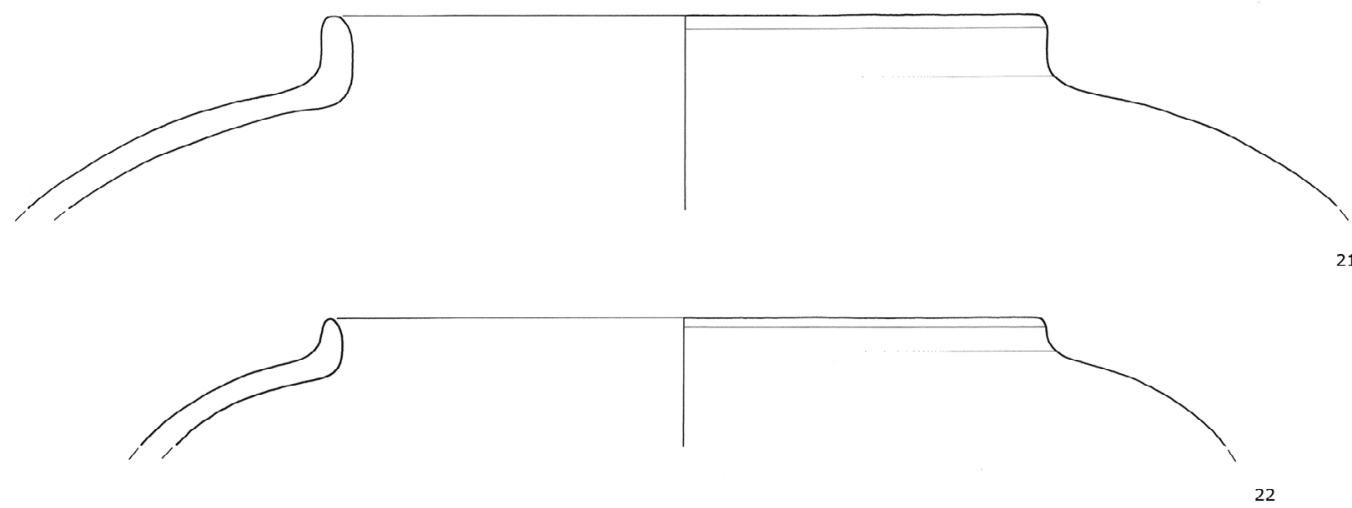

$21 \cdot \sqrt{2}$

22
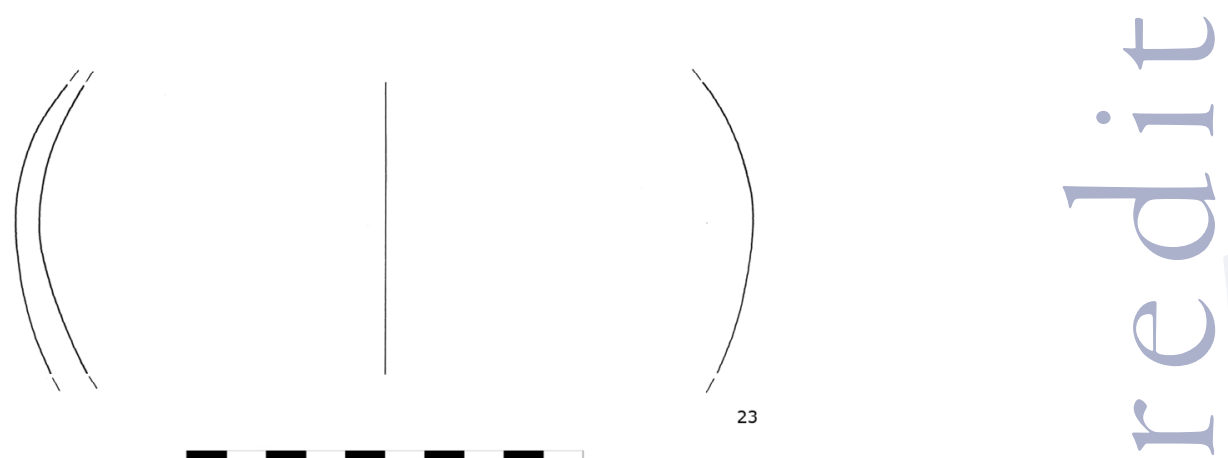

$\square \square \square \square$

23
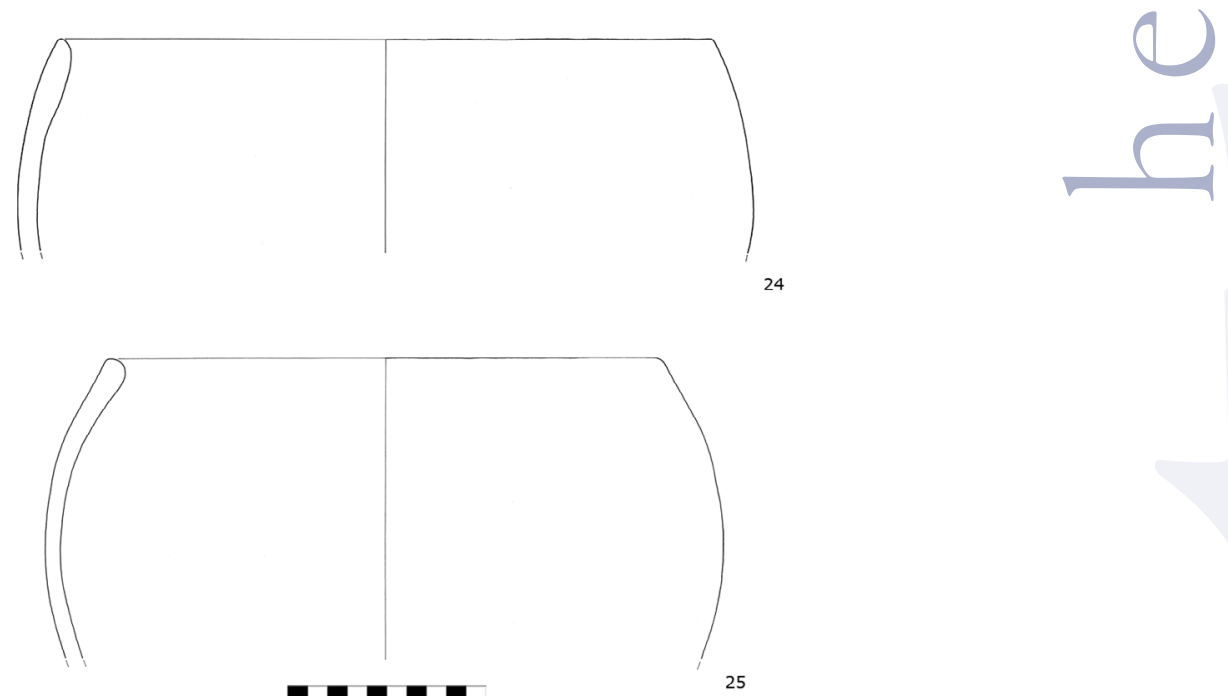

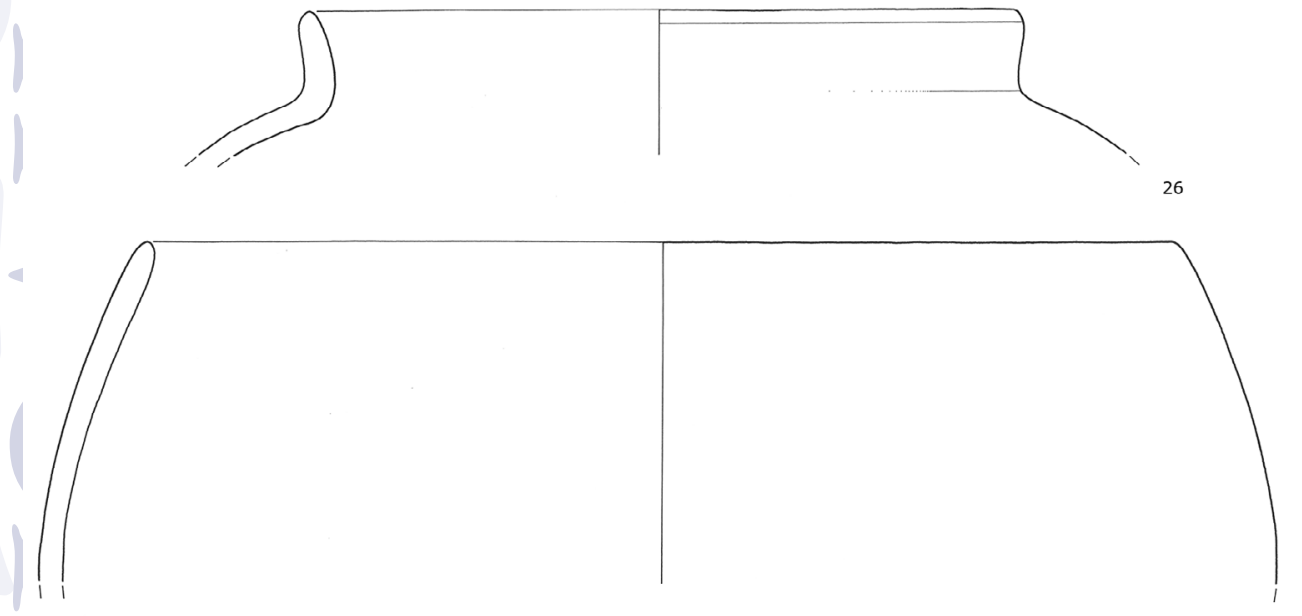

ๆ
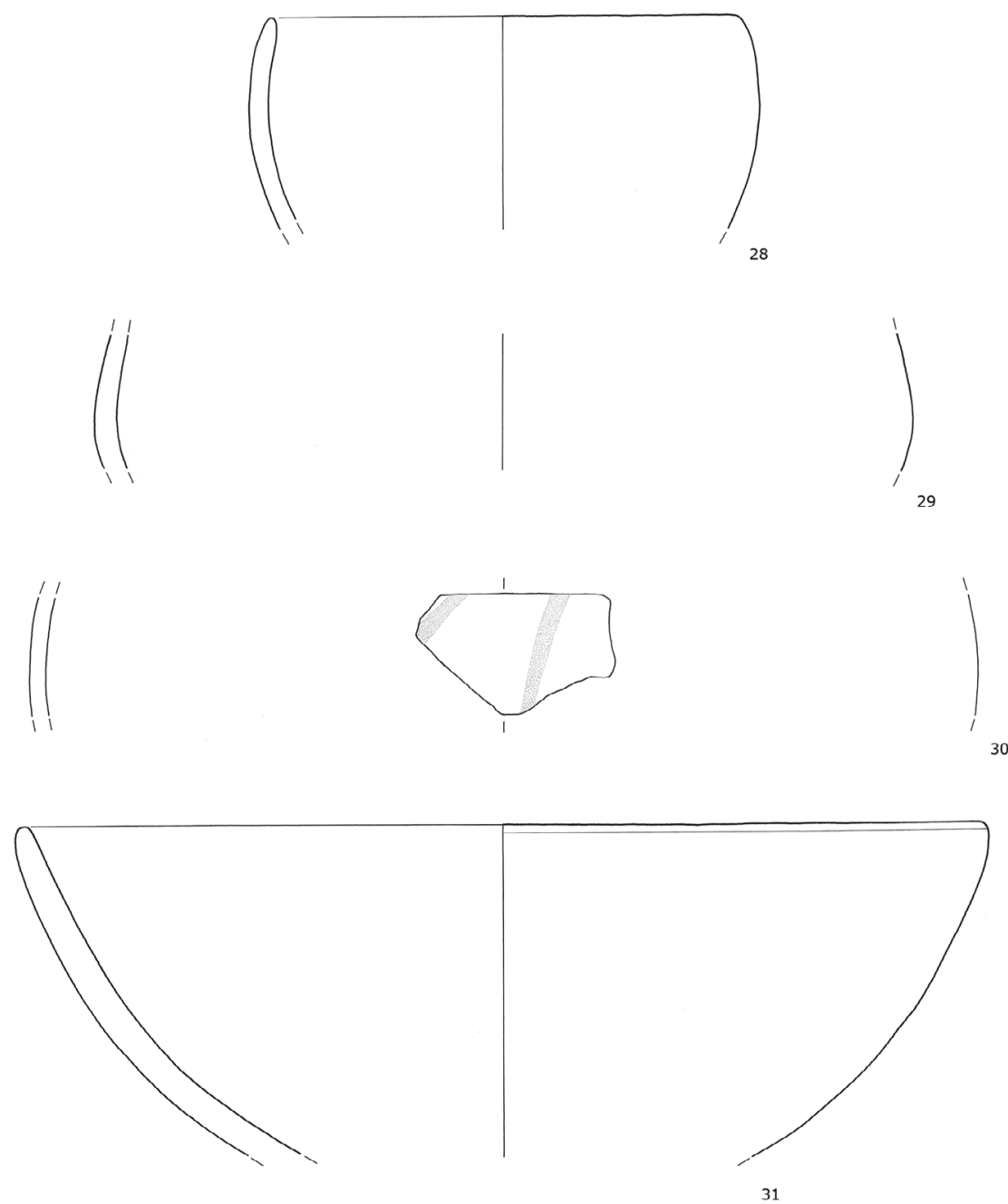

27 

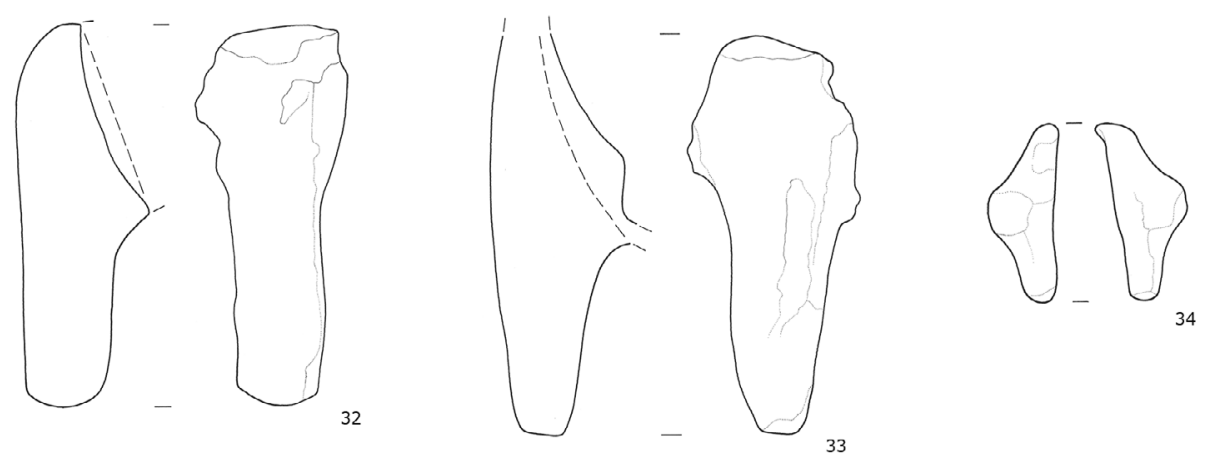

呈
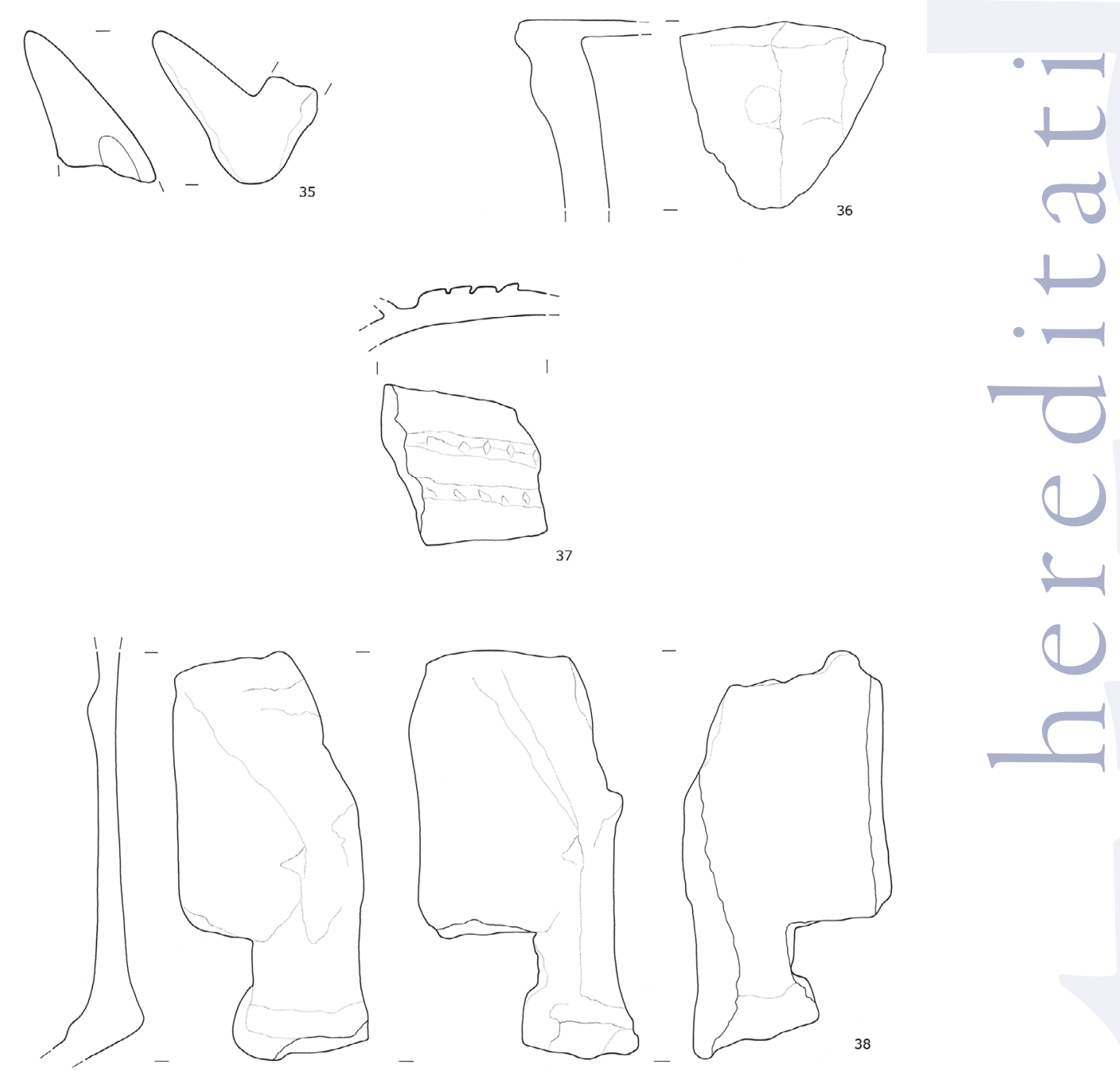


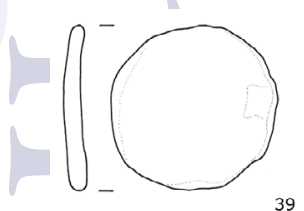

39

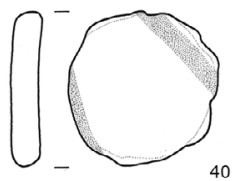

40
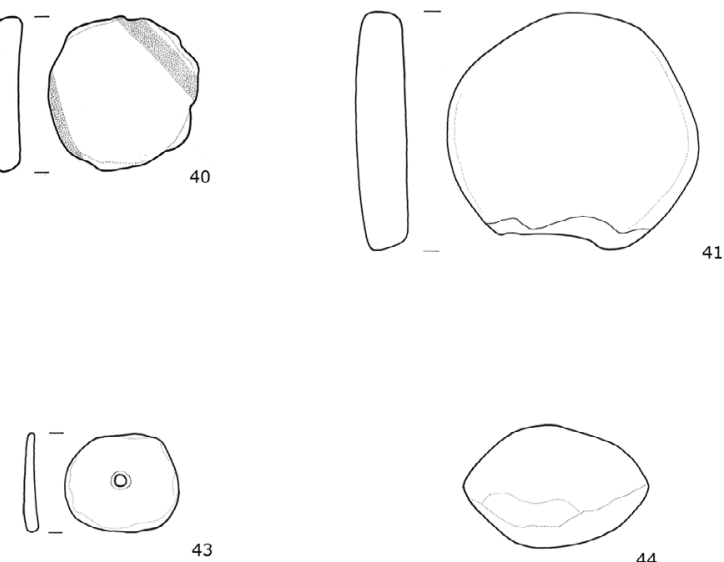

$\approx$
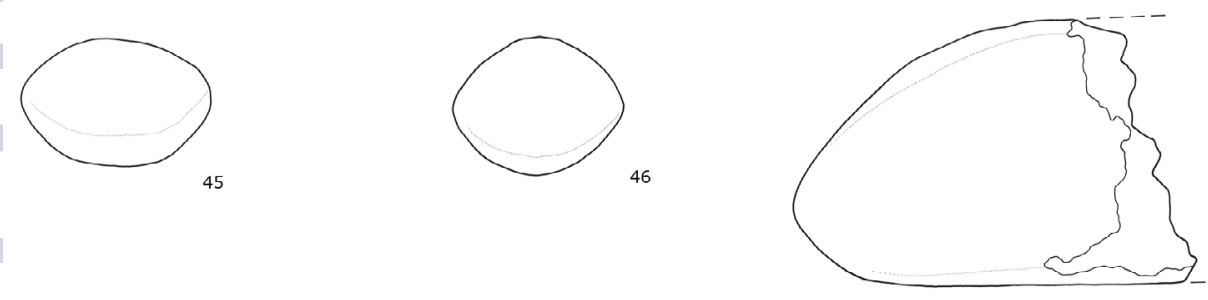

47

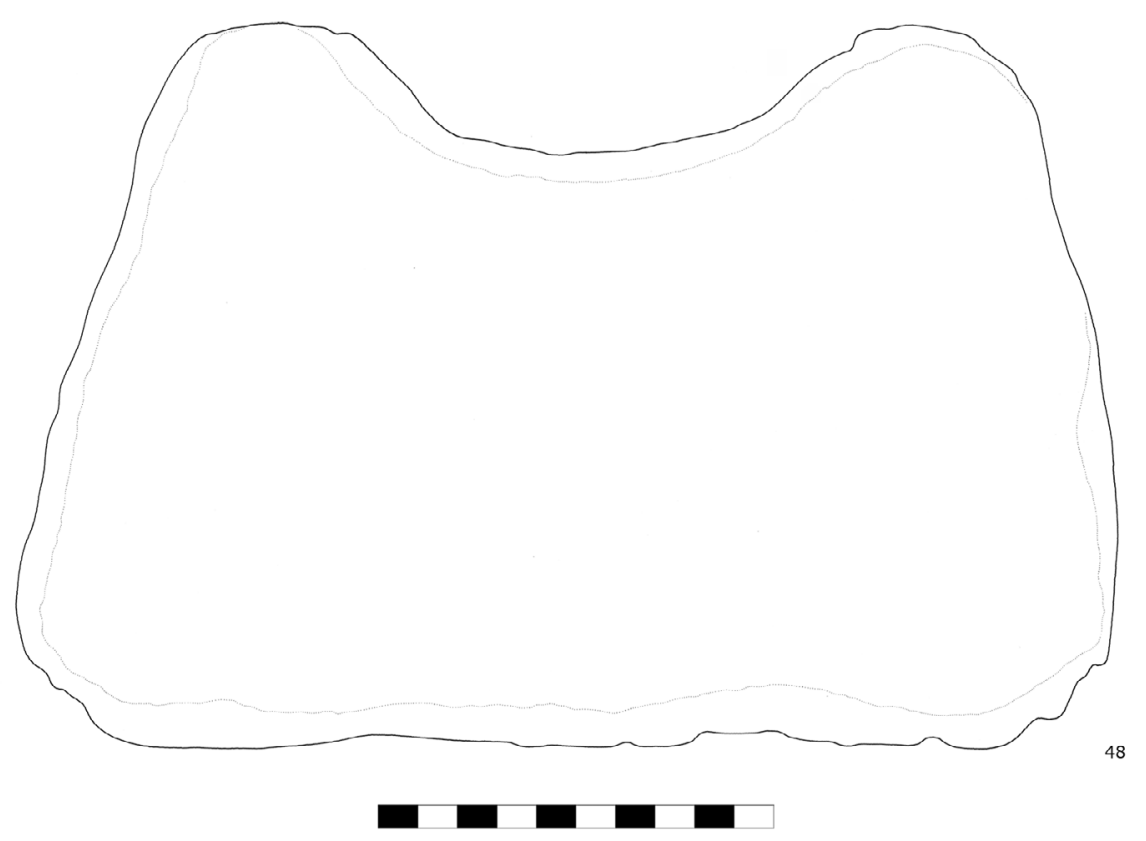




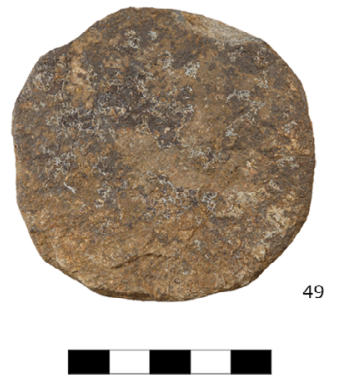

in
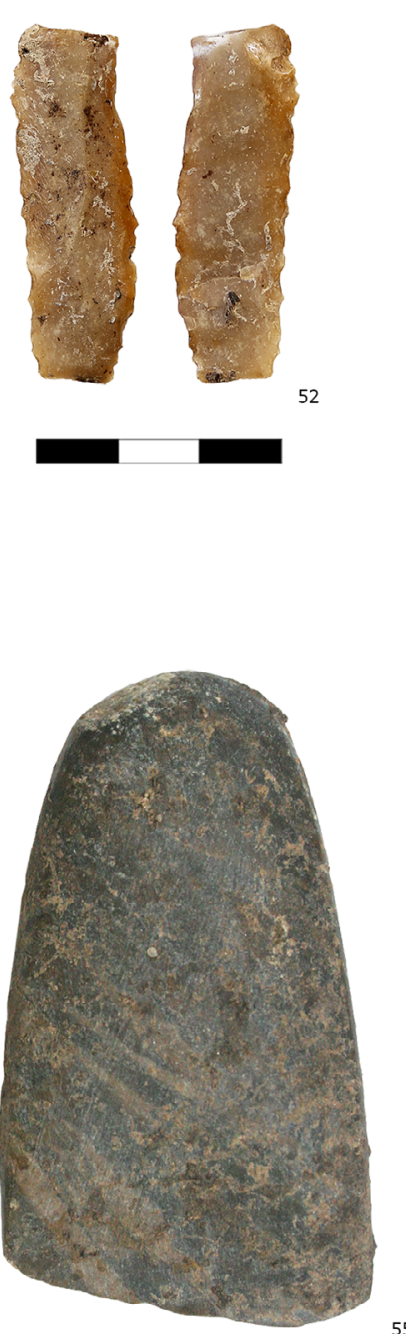

55
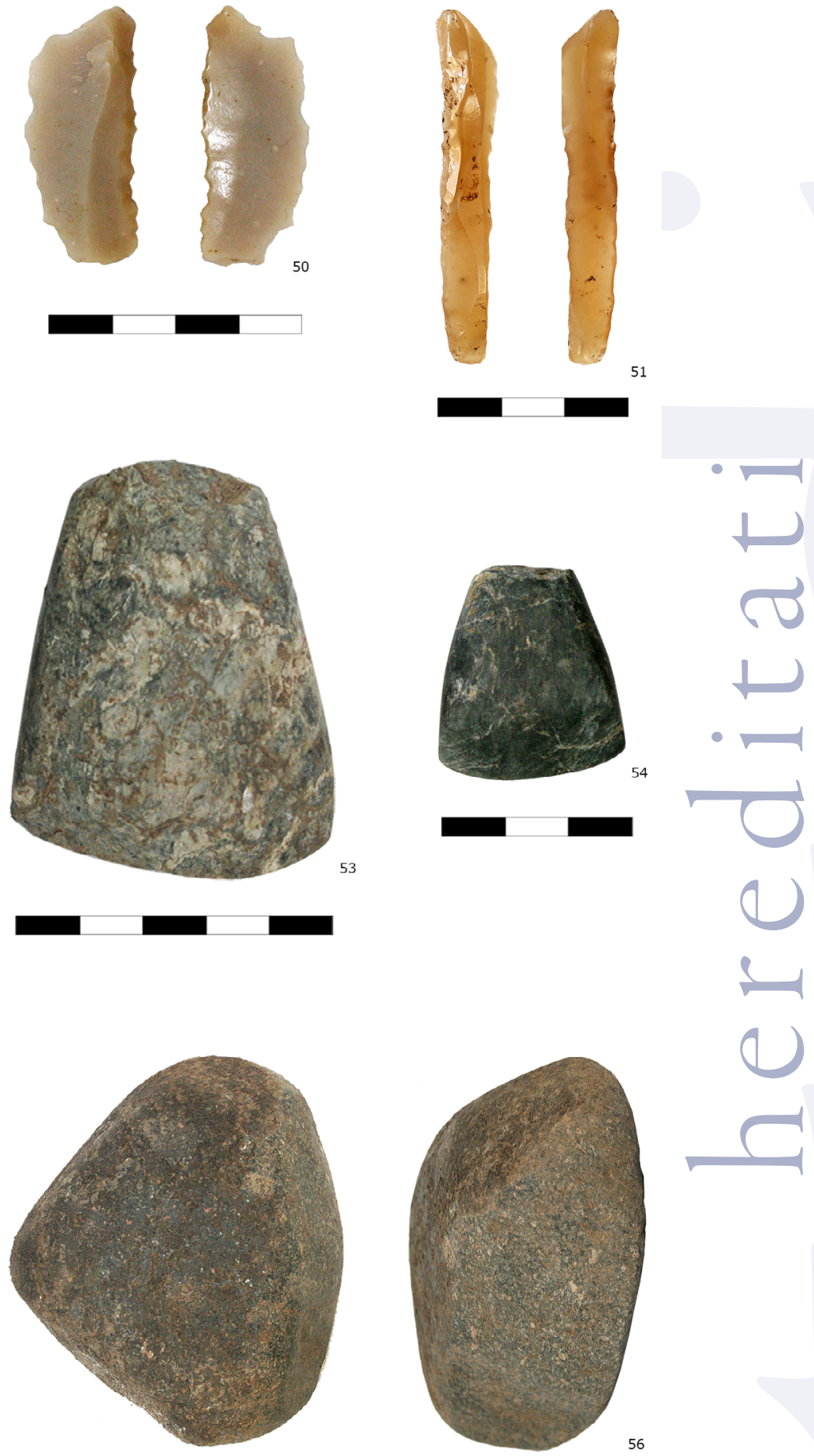
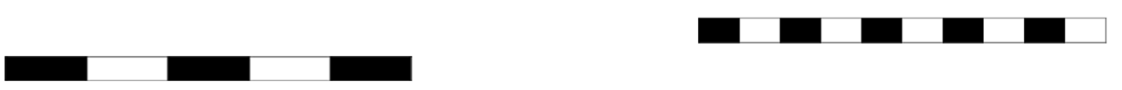
godovinske - neolitske kakor tudi srednjeveške skupnosti, ki sta bivali in soustvarjali življenje na tem prostoru. Na lokaciji Školska Tumba je bilo odkritih več kulturnih faz, kot že povedano, ki jih lahko datiramo v neolitsko obdobje in srednji vek. Najdbe obeh obdobij so za interpretacijo zelo zanimive, čeravno je srednjeveškega gradiva z ozirom na neolitski zbir razmeroma malo. Takšno razmerje med količinama najdb je bilo sicer tudi pričakovano, saj neolitske plasti predstavljajo osnovno formacijo prazgodovinske tumbe, na vrh katere so se kasneje odložile srednjeveške plasti. V nadaljevanju najprej prikazujemo izbor najznačilnejših srednjeveških najdb, podrobneje pa predstavljamo neolitsko arheološko gradivo ${ }^{3}$.

\section{Srednjeveške najdbe}

Med srednjeveškimi najdbami prevladujejo številni odlomki keramičnega posodja (G6, G8, G9). Dominirajo odlomki pekačev t.i. črepenj, ki so $v$ glavnem zelo standardiziranih oblik in načina izdelave. Praviloma so plitki, večjih dimenzij in imajo debela ostenja, nekateri izmed njih pa imajo tudi eno ali dve odprtini na sredini (G8). Med ostalo keramiko je najpogosteje zabeleženo posodje nekoliko bolj grobe fakture in kroglastih oblik, občasno okrašeno z razčlenjenimi plastičnimi rebri. Med srednjeveškim posodjem velja posebej omeniti v celoti ohranjeno amforo, ki je bila odložena na dno večje jame (G9). Keramike fine fakture in t.i. glazirane keramike je med srednjeveškimi najdbami malo. Izpostaviti velja tudi primerek posode $\mathrm{z}$ antropomorfnim slikanim okrasom, ki na prostoru Makedonije predstavlja izjemno redkost (GI). V kontekst keramičnih predmetov lahko prištejemo tudi nekaj primerkov keramičnih pip, ki pa jih je potrebno datirati v nekoliko kasnejše, otomansko obdobje $\left(\mathrm{G}_{3}\right)$.

Kovinske najdbe so za razliko od keramičnega gradiva precej redkejše. Med njimi so še najpogostejši deli nožev, konice puščic in žeblji $\left(\mathrm{G}_{7}\right)$. Za slednje ostaja nejasno, ali so ti predmeti pripadali krstam pokopanih, spričo dejstva, da

Najdbe so izrisali in grafično obdelali Ljubo Fidanoski, Goce Naumov in Janja Tratnik Šumi. Postavitev v table je delo Aleša Ogorelca. so bili nekdaj v bližini odkriti številni srednjeveški grobovi. V zadnji izkopavalni kampanji sicer ni bil odkrit niti en grob ali del oziroma parcialni pokop človeškega skeleta, kar je lahko tudi posledica bodisi majhnega obsega izkopavanj, lokacije sonde, oziroma njene pozicije na periferiji, kjer je bilo lahko tudi že zamočvirjeno okolje. Poudariti je potrebno, da na prostoru raziskav niso bile odkrite ostaline srednjeveških grajenih objektov, tako da je težko dokazljivo tudi, ali ti žeblji pripadajo kakšni grajeni konstrukciji ali ne. Prav tako je bilo odkritih nekaj kovinskih ploščic, za katere morda lahko predvidevamo, da so pripadale nekakšnemu lesenemu predmetu (zaboj, vrata ipd.) (G2).

Med ostalimi srednjeveškimi najdbami naj izpostavimo še dele steklenih zapestnic, ki so narejene v standardnih tehnikah, značilnih za tovrstne srednjeveške izdelke (Gs). Narejene so iz tordirane vlečene steklene paste, tako da ustvarjajo izgled prepleta. V posameznih primerih so tudi večbarvno obarvane zaradi estetskega učin$\mathrm{ka}\left(\mathrm{G}_{4}\right)$. Tovrstne zapestnice in še nekateri drugi predmeti omogočajo natančnejše datiranje evidentiranih plasti v srednji vek.

\section{Neolitske najdbe}

Največji del odkritih arheoloških najdb pripada neolitskemu obdobju, kar niti ni presenetljivo, saj se je naselbina začela razvijati že v zgodnjih fazah neolitika. Med najdbami prevladujejo odlomki keramičnih posod, diskoidni ploščki, keramične krogle za frače, keramične figurine, antropomorfni modeli hiš, žrtveniki, kamnita orodja na klinah in odbitkih, glajene kamnite sekire, žrmlje, gladilci, glineni modeli kruha, uteži, vijčki idr. V tekstu in na slikah predstavljamo le osnovna obeležja odkrite neolitske materialne kulture, hkrati pa izpostavljamo tiste vidike materialne kulture, ki opredeljujejo osnoven vpogled $\mathrm{v}$ gospodarski in duhovni svet neolitskih skupnosti, ki so nekdaj živele na prostoru vasi Mogila. Najdbe tako ne bodo predstavljene nadrobno, skozi svoje tipološke karakteristike in arheološke kontekste, ampak predstavljamo samo njihove glavne značilnosti. 
Keramično posodje predstavlja najobsežnejši zbir odkritih najdb, zato je pri njegovemu izgledu in načinu izdelave zaznati tudi največ variacij. Gledano v splošnem, keramična produkcija najdišča sledi tehnološkim in stilističnim tradicijam neolitske keramike $\mathrm{v}$ Pelagoniji in se $\mathrm{v}$ veliki meri navezuje na tipe, definirane tekom starejših raziskav v Mogili. Kakor na drugih bližnjih neolitskih najdiščih tako tudi na lokaciji Školska Tumba dominira monohromna keramika, oblikovana pretežno v kroglaste posode. Tiste iz starejše poselitvene faze imajo blago navznoter uvito ustje, kar v celoti odgovarja tipološkim karakteristikam zgodnje neolitske keramične produkcije na Balkanu (npr. Gi2, Gi3, Gi4, G23-G25, G27-G30). Prisotno je tudi posodje, katerih ustje je izvlečeno rahlo navzven, kar je predvsem obeležje posod s fino fakturo in tankim ostenjem (npr. Gio, G20, G26). Pri nekaterih kroglastih posodah je ustje kratko in navpično izvlečeno navzgor (npr. GII), medtem ko imajo druge visok cilindričen vrat, značilen tudi za kasnejše faze veluško - porodinske skupine (npr. G15, G16, G19, G21-G22).

Število bikoničnih posod, katere so prisotne v obeh neolitskih fazah, je razmeroma majhno (npr. G2o). Za njih je značilno, da imajo največkrat fino fakturo in tanko polirano površino ostenja, ki je črne ali temno sive barve. Poleg teh posod so prisotne tudi skodele $z$ grobo ali fino fakturo, katere imajo neredko precej velike dimenzije (npr. Gi7-Gi8, G3I). Dna so pri večini posodja oblikovana ravno, čeprav so lahko tudi blago privzdignjena. V tem kontekstu je potrebno omeniti tudi nekaj primerkov fragmentiranih nog, ki pripadajo bodisi ritonom oz. posodam na treh oz. štirih nogah (npr. $G_{32}-G_{33}$ ). Ročaji na posodah so praviloma redki, kar je ena od osnovnih značilnosti starejših in srednje neolitskih najdišč v Pelagoniji. Ponekod so prisotne tudi zankaste aplikacije, katere bi lahko delovale kakor ročaji, čeprav se ne more izključiti tudi njihova dekorativna vloga. Za razliko od njih, elipsoidnih aplik $s$ tanjšimi vertikalnimi in horizontalnimi perforacijami praktično ni, kar je presenetljivo, glede na to, da se le-te pogosto po- javljajo na drugih neolitskih lokacijah v Makedoniji, kakor tudi širše na Balkanu.

Tehnološke značilnosti lončenine oziroma faktura njihove izdelave je bila pri večini posodja groba, čeprav ni malo niti tistih s polirano površino. Med posodjem z grobo fakturo dominirajo monohromne posode s široko odprtim ustjem, ki so lahko bledo rjave, rjave ali sive barve (npr. Gi7, Gi8, G3I). Njihove dimenzije sicer močno variirajo, so pa bili zelo pogosti večji lonci, ki so se najverjetneje uporabljali za shranjevanje in pripravo hrane. Posodje s fino fakturo je največkrat temno rdeče, oker in sive barve, medtem ko v mlajši neolitski fazi dominira predvsem posodje s črno obarvano in polirano površino. V glavnem so to kroglaste posode $s$ tankimi ostenji, redkeje pa tudi takšne z bikoničnim profilom.

Posodje lahko opredelimo v različne variante $\mathrm{z}$ vidika oblike kot tudi z vidika okrasa. Nekateri primerki posodja, grobe fakture, so okrašeni z barbotinom. Lahko so okrašeni z neorganiziranim barbotinom, pri katerem je grob premaz iz gline nanesen na ostenje v naključni obliki, lahko pa tudi s t.i. organiziranim barbotinom, kjer je bil glinen nanos razporejen $\mathrm{v}$ pravilne linije $\mathrm{s}$ pomočjo prstov (npr. GI3, Gi8, G25). V vseh evidentiranih primerkih je bil barbotin nanesen na trup posode, torej pod največjim obodom, kar morebiti nakazuje tudi na njegovo funkcionalno vlogo. $\mathrm{Na}$ posameznih primerkih grobega posodja je bil okras izdelan s tankimi, s prstnimi odtisi razčlenjenimi plastičnimi rebri, ki spominjajo na vrvico. Tovrsten ornament je poznan na keramiki številnih drugih neolitskih najdišč $\mathrm{v}$ Makedoniji in na Balkanu, dokumentiran pa je tudi na najdiščih kasnejših prazgodovinskih obdobij. Poleg plastičnih okrasov je neolitsko posodje iz Mogile okrašeno še $z$ vrezanimi okrasi tankih plitvih linij in odtiskovanjem nohtov. $\mathrm{Za}$ razliko od barbotina pa so te dekorativne tehnike dosti bolj redke. Tudi posode s slikanim okrasom so precej redke. Slikan okras je izveden z belo barvo, motiv pa največkrat prikazuje tanke ravnolinijske in krivolinijske črte, katere so značilne za faze velušina - porodin I - IV (npr. G30, G4o). Tako redko pojavljanje belo-slikane kera- 
mike ne preseneča, glede na to, da je bila raziskovalna sonda locirana na sami periferiji naselbine. Arheološke plasti in faze poselitve so na tem delu naselbine precej tanjše, kar kaže na to, da je bilo samo življenje na periferiji precej manj intenzivno kot $v$ njenem centralnem delu. Pri izkopavanjih $v$ 70-ih letih, ki so bila izvedena $v$ centralnem delu naselbine, je bilo namreč odkritega precej več slikanega posodja s karakterističnimi motivi, značilnimi za zgodnji neolitik Pelagonije (Simoska et al. 1979, 9-30).

Obseg ostalih izdelkov iz keramike je glede na produkcijo keramičnega posodja relativno maloštevilen. Med nje sodijo razna funkcionalna orodja kakor tudi predmeti, namenjeni simbolični komunikaciji in obredju. $\mathrm{V}$ drugo skupino predmetov sodijo keramične figurine, antropomorfni modeli hiš in modeli hiš, narejeni v obliki mizic oziroma t.i. žrtveniki. Figurine obsegajo nekaj antropomorfnih in zoomorfnih upodobitev, izdelanih $\mathrm{v}$ domeni pelagonskih neolitskih tradicij. Antropomorfne figurine so malih dimenzij in največkrat so ohranjeni ostanki glave in nog. Glave so izrazito stilizirane, prikazan je nos, kateri predstavlja edin prisoten element na obrazu. Ena od teh figurin ima ohranjen tudi del telesa, na katerem so vrezane linije kot tudi desna roka, v kateri je izdelana perforacija. Noge so izdelane v standardni obliki brez posebej nakazane steatopigije. En primerek noge je precej porozen in zaradi tega $\mathrm{v}$ precejšnji meri poškodovan, medtem ko ima druga votlo notranjost (npr. G34). Za razliko od njih, drug primerek predstavlja sestavni del desne polovice fragmentirane figurine. Takšno namerno fragmentiranje figurin je prisotno tudi drugje v Pelagoniji, precej pogosto pa je tudiv drugih predelih Makedonije (Naumov 2015).Zoomorfne figurine so redkejše, odkrit je bil vsega en primerek (npr. G35) in sicer predstava rogate živali; podobne so bile odkrite tudi ob starejših izkopavanjih (Simoska in Sanev 1976; Simoska et al. 1979, 9-30).

$\mathrm{V}$ okvir človeških upodobitev sodijo tudi antropomorfni modeli hiš. Najdenih je nekaj odlomkov cilindrov in delov hiš. $\mathrm{Na}$ enem od bolje ohranjenih cilindrov je ohranjen tudi ob- raz v njegovem spodnjem delu. Ohranjena je trikotno oblikovana spodnja čeljust (brada), ki se zaključuje s ušesom (npr. G38) izvedba upodobitve je tipična za antropomorfne modele v Pelagoniji (Naumov 20I4). Oči in usta so izdelani s pomočjo elipsastih aplikacij, nos je poškodovan. Upodobitev nosa je prikazana na enem od drugih primerkov, le da ta močno spominja na upodobitev tega dela obraza, kateri se sicer praviloma nahaja na antropomorfnih posodah in ne na modelih hiš (npr. G36). Pri izkopavanjih so bili odkriti tudi posamezni odlomki zadnjega dela glave, kjer je izdelana aplikacija v obliki zanke in rebro na tilniku. Oboje predstavlja karakteristično upodobitev na antropomorfnih modelih hiš $\mathrm{v}$ Makedoniji (npr. G36). Z notranje strani je izdelan navpični kanal, ki pelje do odprtine na temenu, kakor tudi nekaj vodoravnih vdolbin, katere so nastale kot odtis lesene armature, ki je služila kot pomagalo pri izdelavi cilindra. Iz skupine primerkov antropomorfnih modelov hiš so bili odkriti tudi nekateri odlomki strehe, na katere so aplicirani dekorativni motivi, tipični za tovrstne najdbe in kateri najverjetneje predstavljajo odtise določenih likov ali pa upodobitev strešne kritine neolitske hiše (npr. G37).

Modeli keramičnih hiš v Pelagoniji nimajo samo antropomorfnih obeležij, ampak pogosto predstavljajo nekakšne male mizice $\mathrm{z}$ arhitektonskimi značilnostmi, katere so $\mathrm{v}$ arheološki literaturi pogosto poimenovani kar kot žrtveniki (Naumov 2011, 89-129). Tovrstne najdbe, specifične za Pelagonijo, so bile odkrite tudi v Mogili in to v najstarejših plasteh naselbine. Eden takih odlomkov je bil odkrit tudi v manjši jami, vkopani v glineno geološko osnovo. Tukaj je potrebno opozoriti, da so takšni trikotni motivi prisotni tudi na t.i. antropomorfnih modelih hiš, tako, da je v tem trenutku težko opredeliti ali morda ta odlomek ne pripada tej varianti. Če vzamemo v obzir, da antropomorfne variante kot tudi žrtveniki predstavljajo bivališča oziroma gospodarske objekte, bi lahko sklepali, da takšno deponiranje odlomka modela hiše predstavlja določeno simbolično aktivnost. Med najdbe, ki bi lahko imele simbolična obeležja, sodi tudi en prime- 
rek keramičnega »hlebčka«, ki je prelomljen na polovico (npr. G47). Takšni predmeti so značilna pojava med neolitskimi najdbami na prostoru Republike Makedonije, tako da je povsem možno, da je kruh na specifičen obreden način povezan s skupnostjo; predmet pa izraža tudi njegovo simbolno vlogo (Naumov 2008, I85-204).

Orodja predstavljajo dokaj številčno skupino artefaktov, ki so lahko izdelani iz kamna ali keramike. Med keramičnimi predmeti so najpogostejše manjše krožne ploščice, izdelane iz ostenj razbitega posodja. Nekateri izmed njih imajo v središču izdelano perforacijo, na nekaterih so ohranjene sledi belega slikanega ornamenta (npr. G39-G4I, G43). Njihova funkcija ostaja še vedno nejasna, čeprav se predpostavlja, da so bili uporabljeni bodisi kot podstavki ali kot uteži (Simoska in Sanev 1975, 25-85). Sicer pa so imele uteži konično obliko, nekatere izmed njih so bile tudi okrašene z vrezi (npr. $\mathrm{G}_{42}$ ). Te uteži so se najverjetneje uporabljale kot uteži za ribiške mreže, ali pa so bile uporabljane pri tkanju, čeprav sledi uporabe, ki bi kazale na njihovo uporabo, ni. V kontekst tkalske dejavnosti bi morda sodili tudi kroglasti vijčki, odkriti v različnih plasteh (npr. G43). Med izdelke iz žgane gline sodijo tudi t.i. projektili za frače, ki predstavljajo eno izmed številčnejših skupin predmetov. So prepoznavna značilnost neolitske gospodarske ekonomije v Pelagoniji, namreč drugje v Makedoniji so bodisi redki ali pa sploh niso prisotni. Njihova elipsoidna oblika in velikost sta dokaj standardizirani in ne odstopajo od ustaljenih načinov izdelave (npr. G44-G46). Med zanimive keramične predmete sodi tudi večji podstavek z vboklo zgornjo površino ( $\left.\mathrm{G}_{4} 8\right)$, katerega namembnost za enkrat še ni povsem pojasnjena.

Med kamnitim orodjem so najpogosteje prisotne retuširane kline, izdelane iz kremena in pa glajene sekire, izdelane iz tufa. Strgala so največkrat izdelana iz t. i. medenega kremena, so tanjših in podolgovatih oblik, pogosto s sledmi uporabnih retuš (npr. G50-G52). Del teh kremenovih artefaktov je manjših dimenzij in so jih najverjetneje vstavljali v lesene ali koščene nastavke, da bi jih lahko uporabljali kot srpe.
Sekire so izdelane v standardnih okvirih, običajno so manjših ali srednjih dimenzij, pravokotnih do nekoliko oglatih zaobljenih oblik (npr. G53-G55). To lahko nakazuje na njihovo pogosto uporabo ali pa na morebitno socialno-simbolično funkcijo, kar pa bi dokazale samo nadaljnje temeljite raziskave. $\mathrm{V}$ skupino kamnitih orodij bi sodile tudi nekoliko masivnejši tolkači oz. gladilci, ki so najverjetneje služili za izdelavo in ostrenje kamnitih orodij (npr. G56). Za razliko od kamnitih orodij, takšnih, izdelanih iz kosti ni prav veliko. Najden je bil en sam obdelan del jelenovega roga, katerega funkcija ni znana.

\section{Zaključek}

Arheološke raziskave na lokaciji Školska Tum ba, izvedene v letu 20I4, so v veliki meri potrdila spoznanja in rezultate raziskav na isti lokaciji v letu 1977 (Todorović et al. 1980). Razlika je le $\mathrm{v}$ prepoznavanju in definiranju sosledja posameznih faz naselbine ali t.i. kulturnih horizontov, oziroma v definiranju še ene kasnejše faze, objektivirane skozi zgornje plasti naselbine. V tem smislu lahko potrdimo, da imamo opravka $\mathrm{s}$ tumbo, ki se je formirala $\mathrm{v}$ zgodnjem neolitiku in je trajala do njegovih zaključnih faz; lokacija pa je bila ponovno naseljena v srednjem veku. Arheološke ostaline, ki bi pričale o poselitvi v ostalih obdobjih prazgodovine in v obdobju antike, niso bile potrjene, čeprav so se v preteklosti omenjale tudi najdbe bronaste dobe na drugih tumbah v Mogili, kot so to Tumba Sredselo in Ronjevska Tumba (Simoska et al. 1979, 9-30; Simoska I996a, 36). V tem smislu se Školska Tumba dobro vklaplja v del pelagonskih tumb, ki so bile poseljene edino $\mathrm{v}$ obdobju neolitika in kasneje še v srednjem veku. Za razliko od njih pa imajo nekatere druge potrjeno kontinuiteto od neolitskega do eneolitskega obdobja oziroma bronaste dobe. Niti ena od njih pa do sedaj nima potrjene uporabe $\mathrm{v}$ času železne dobe.

Glede na geografska obeležja lokacije Školska Tumba, lahko potrdimo, da je le-ta bila formirana na peščenih aluvialnih naplavinah, ki so bile malo privzdignjene nad lokalnim reliefom. Prostor je predstavljal izjemno dobro mikro- 
-morfološko lokacijo, primerno za formiranje večjega naselja tik nad močvirnatimi predeli tega dela pelagonske kotline. Lokacija je omogočala relativno hitro dostopnost hrane in drugih resursov iz okoliških gozdov, rek in jezer, dobro pa so uspevale tudi žitarice na plodnih poljih. Zaradi tega ne preseneča, da je v bližini Mogile nastalo na desetine prazgodovinskih naselij - tumb. Kot je bilo izpostavljeno že v uvodnem delu, se za nekatere od njih, npr. Tumba Sredselo, Tumba Selska Crkva in Školska Tumba, lahko smatra, da so del enega samega velikega naselja, katerega pa je modernizacija vasi Mogila razčlenila na več majhnih lokacij. Takšna večja naselja so poznana tudi v drugih predelih Pelagonije, nedavno pa so bili registrirani tudi prostorski areali, ki so jih te naselbine nekdaj obsegale (Naumov in Stojkoski 2015, 169-183). Z obzirom na to, je treba razumeti, da je Školska Tumba le sestaven del te večje naselbine, kar potrjuje tudi izjemna podobnost neolitskega gradiva, odkritega ob izkopavanjih na lokacija Tumba Sredselo v letu 1975 (Simoska et al. 1979, 9-30).

Na osnovi značilnosti odkritih arheoloških najdb se lahko potrdi, da je bila ta naselbina prvič naseljena v zgodnjem neolitiku, kar je jasno razvidno iz keramičnega gradiva, kakor tudi iz radiokarbonskih datacij, ki so bili pred kratkim na novo kalibrirani (Naumov 2016a). Glede na kalibrirane datacije je bila ta lokacija prvič naseljena nekoliko po začetku šestega tisočletja, radiokarbonske datacije pa potrjujejo tudi poselitev na prehodu med šestim in petim tisočletjem pr.n.št.. Takšna datacija povsem sovpada z začetkom naselitve na lokacijah Veluška Tumba in Tumba pri Porodinu, kakor tudi Čuka pri mestu Topolčani (Naumov 20ı6a). Čeprav ti podatki temeljijo na analizah maloštevilnih primerkov in ostajajo diskutabilni, pa se vsaj za enkrat lahko potrdi, da so neolitske skupnosti v Pelagoniji formirale svoja prva naselja v samem začetku šestega tisočletja pr. n. št. Vsekakor pa se lahko dosedanje poznavanje povsem spremeni $\mathrm{z}$ analizami novih primerkov $\mathrm{z}$ obravnavanih lokacij. V času arheoloških raziskav na lokaciji Školska Tumba so bili namreč iz vseh plasti evidentirani in shranjeni vzorci, katerih analize bi lahko potrdile ali pa korigirale dosedanjo kronologijo te neolitske naselbine.

Kot je bilo že zgoraj omenjeno, lahko zgodnji neolitik potrdijo tudi keramične najdbe. Za najzgodnejše faze naselbine je značilno posodje z belo slikanim okrasom v obliki motivov izdolženih linij v kompleksni kompoziciji, kar so nakazovale že najdbe predhodnih izkopavanj, sočasno z njimi pa je tudi posodje, okrašeno $s$ t.i. motivom sigme (Simoska et al. 1979, 9-30; Todorović et al. 1980). V tej fazi je največ registriranih kroglastih posod in loncev z izraženim bikoničnim ostenjem, bolj poredko pa so prisotne bolj odprte forme posod. Okrašeni so pretežno z odtiskovanjem, v nekaj primerih tudi barbotinom.

Sledi 2. faza neolitske poselitve, ki pa je bila že precej poškodovana s srednjeveškimi posegi oz. jamami. Glede na radiokarbonske analize bi ta faza naj pripadala obdobju med 6. in 5. tisočletjem pr. n. št., vključuje pa tudi gradivo, katero je mogoče datirati v sredino 6. tisočletja pr. n. št. Čeprav se v tej fazi nadaljuje predhodna keramična tradicija, pa je vseeno treba izpostaviti proizvodnjo fine, črne polirane keramike bikoničnih oblik s krajšim izvihanim ustjem. Poleg omenjenih najdb so še vedno $\mathrm{v}$ uporabi tudi kroglaste posode, okrašene s slikanimi motivi (rombi, ravnolinijski in krivolinijski motivi), razmeroma pogosto je $\mathrm{v}$ uporabi tudi barbotin.

$\mathrm{V}$ predhodnih izkopavanjih je bila definirana tudi 3. neolitska kulturna faza, v kateri pa se je nahajala tudi srednjeveška keramika. Tekom izkopavanj v letu 2014 na periferiji naselbine pa se je pokazalo, da so bile plasti te faze precej poškodovane $s$ kasnejšimi srednjeveškimi posegi na prostoru, zaradi česar se je tudi v plasteh 3. faze nahajala oblica srednjeveških najdb. Leta 2014 je bila tekom raziskav evidentirana tudi 4. faza, katero pa lahko označimo za recentno in predstavlja najmlajše posege na sami lokaciji. Plasti vsebujejo premešane neolitske in srednjeveške najdbe, kakor tudi tiste, ki sodijo v 20. stoletje. Pri izkopavanjih centralnega dela te velike $\gg$ tumbe $\ll$, katera formalno pripada lokaci- 
ji Tumba Sredselo, so bili odkriti tudi posamezni odlomki, kateri so datirani v bronasto dobo. Tovrstne najdbe na periferiji naselbine niso bile evidentirane.

V zgodnje neolitski fazi so bile dokumentirane tudi nekatere arhitekturne ostaline. V najnižji plasti so bile registrirana ostaline polkrožne konstrukcije, izdelane iz tanjših kolov, lociranih na izravnanem platoju. Poleg njih so bile evidentirane tudi ostaline objekta, grajenega iz masivnejših kolov, ki bi lahko bil prvemu sočasen ali pa zgrajen nekoliko kasneje. Takšne oblike zgradb na drugih lokacijah v Pelagoniji niso poznane, kar pa bi lahko bila posledica tudi dejstva, da so bile dosedanje raziskave pretežno locirane na centralnih delih naselij. Lahko se predvideva, da so takšne konstrukcije v periferijah naselbine imele gospodarski karakter; tudi glede na njene manjše dimenzije. Če vzamemo v obzir še dejstvo, da je bil ta del Pelagonije močvirnat, je možno, da so se gradile tudi stavbe na koleh zaradi zaščite pred vodo. Takšne stavbe so se gradile v Mogili tudi še v drugi polovici 20. stoletja. In četudi je prostor že delno osušen in so se v pokrajini večino leta ohranjala le jezerca, je ob večji količini padavin celotno področje bilo podvrženo poplavam, kar so dokazale tudi poplave 2015.

Tudi keramični modeli hiš so evidentirani v najnižjih plasteh naselbine, en odlomek pa je bil namenoma deponiran $\mathrm{v}$ eni od manjših jam, vkopanih v geološko osnovo, oziroma geološko plast, na kateri je kasneje osnovana zaenkrat najstarejša konstrukcija, registrirana $\mathrm{v}$ Mogili. To bi lahko potrjevalo, da je bil kultno obredje v bivališčih oz. gospodarskih objektih, kateri so značilni za Pelagonijo, prisotni že v najstarejših fazah neolitika tega prostora.

To vsekakor potrjujejo tudi sočasni predmeti iz drugih najdišč Pelagonije, kot so Porodin, Optičari, Topolčani in dr. Za razliko od teh arhitekturnih modelov se njihove antropomorfne variante pojavljajo nekoliko kasneje tako v Mogili kakor tudi na drugih neolitskih naseljih v Pelagoniji. Tisti, najdeni v Školski Tumbi, imajo običajne značilnosti modelov $\mathrm{z}$ masivnimi cilindri $\mathrm{z}$ obrazom apliciranim $\mathrm{v}$ trikotno polje, kakor tudi »zdolnište« na pokrovu od hiše. V kontekst antropomorfnih reprezentacij se lahko vključijo tudi nekatere figurine, katere ne odstopajo mnogo od pelagonskih tradicij, ena izmed njih pa ima tudi obeležja namerne fragmentacije, kar je spričo drugih regij Makedonije tukaj zelo redko (Naumov 20I5). Kamnita orodja so primerljiva z najdbami ostalih pelagonskih najdišč, pri čemer pa opažamo, da so najštevilčnejši projektili za frače, sekire in kamnite kline.

Glede na povedano se lahko zaključi, da je osrednja neolitska tumba $\mathrm{v}$ Mogili, katere del predstavlja tudi Školska Tumba, ena od največjih in najmasivnejših tega časa v Pelagoniji. Glede na meritve njenega centralnega dela iz izkopavanj v letu 1977 , višina celotne stratifikacije plasti na njenem najvišjem delu znaša 6,09 $\mathrm{m}$, čeprav je v Arheološki karti Makedonije navedeno, da je 6,90 m (Simoska et al. 1979, 9-30; Simoska 1996a, 36). Takšna višina naselbinskih plasti ne preseneča, glede na njen centralni značaj v odnosu do številnih, nekoliko manjših tumb, ki so registrirane v njeni neposredni bližini. Poleg tistih, že poznanih iz 70-ih let 20. stoletja, sta bili $\mathrm{v}$ letu 2015 evidentirani še dve novi (Naumov in Stojkoski 2015; Naumov 2016a). Celotna prostorska situacija evidentiranih lokacij potrjuje, da ima Mogila centralno pozicijo med najdišči v tem delu Pelagonije, h kateri so gravitirali številni manjši zaselki, ki so nastali bodisi v času neolitika ali tudi v katerem od kasnejših prazgodovinskih obdobij. Takšni centri so prepoznani tudi v drugih predelih Pelagonije, zaradi česar bi lahko sklepali, da so le-ti imeli pomembnejšo vlogo v ekonomski komunikaciji kot manjši zaselki. Značaj centralne naselbine v Mogili za enkrat še ni natančno definiran, kakor tudi še ni pojasnjeno ali so gravitirajoči zaselki s centralno naselbino sinhronega nastanka ali pa so le-te nastale kasneje. V vsakem slučaju pa njena lokacija kakor tudi arheološko gradivo dokazujeta, da je bila naselbina že v zgodnjem neolitiku v središču ekonomskih tokov prvih poljedelcev v Pelagoniji in je znatno prispevala $\mathrm{k}$ učvrstitvi ekonomskih standardov in simboličnih principov zgodnje neolitskega obdobja. 


\section{Povzetek}

Območje Pelagonije (Severne Makedonija) kot prostor intenzivne neolitske poselitve je arheološki javnosti poznano že precej časa. Velik raziskovalni interes se je za pelagonska prazgodovinska najdišča pojavil tik po drugi svetovni vojni. Prva izkopavanja je tedaj izvedel Josip Korošec na Grgur Tumbi, izpostaviti pa velja tudi temeljno arheološko raziskavo na lokaciji Tumba pri Porodinu. »Zlata doba « preučevanja prazgodovine Pelagonije je nastopila v sedemdesetih letih 20. stoletja, ko so bila izpeljana sistematična rekognosciranja in sondažna izkopavanja na številnih lokacijah v centralnem delu Pelagonije. Takrat so se vršile sistematične raziskave na najdiščih Veluška Tumba pri Porodinu, Mogila, Optičari, Trn, Karamani, Dobromiri, Radobor in drugje.

Pelagonija kot specifičen arheološki fenomen ponovno postane središče zanimanja širše strokovne javnosti šele v drugem desetletju 21. stoletja. V okviru te iniciative je bilo na periferiji lokacije Školska Tumba v Mogiliv sodelovanju makedonsko - slovenske ekipe v letu 2014 vršeno arheološko sondiranje, usmerjeno v prepoznavanje stratifikacije naselbine. Sondiranje je v veliki meri potrdilo spoznanja in rezultate raziskav leta 1977 na isti lokaciji. Razlika je le v prepoznavanju in definiranju sosledja posameznih faz naselbine ali t.i. kulturnih horizontov, oziroma v definiranju še ene kasnejše faze, objektivirane skozi zgornje plasti naselbine. V tem smislu lahko potrdimo, da imamo opravka stumbo, ki se je formirala v zgodnjem neolitiku in je trajala do njegovih zaključnih faz; lokacija pa je bila ponovno naseljena v srednjem veku. Arheoloških ostalin mlajših prazgodovinskih obdobij in antike nismo zasledili.

V bližini Mogile je evidentiranih na desetine prazgodovinskih naselij - tumb; za nekatere od njih, npr. Tumba Sredselo, Tumba Selska Crkva in Školska Tumba, se lahko smatra, da so bile del enega samega velikega naselja, katerega pa je modernizacija vasi Mogila razčlenila na več mikro lokacij. Predvideva se, da je bila lokacija Školska Tumba le sestaven del večje naselbine, kar potrjuje tudi izjemna podobnost neolitskega gradiva, odkritega ob izkopavanjih na lokacija Tumba Sredselo v letu 1975. Arheološko sondiranje v letu 2014 je pokazalo, da je na periferiji lokacije Školska tumba možno definirati 4. faze poselitve. Najstarejša poselitev (I. faza poselitve) sodi v čas zgodnjega neolitika, kar potrjujejo ostanki arhitektire in odkrite arheološke najdbe, predvsem keramično gradivo. Časovni umestitvi pritrjujejo tudi radiokarbonske datacije. Prvič je bila ta lokacija naseljena nekoliko po začetku šestega tisočletja, poselitev pa je izpričana tudi na prehodu med šestim in petim tisočletjem pr.n.št. Takšna datacija povsem sovpada z začetkom naselitve na lokacijah Veluška Tumba in Tumba pri Porodinu, kakor tudi Čuka pri mestu Topolčani. Za najzgodnejše faze naselbine je značilno posodje z belo slikanim okrasom v obliki motivov izdolženih linij v kompleksni kompoziciji, kar so nakazovale že najdbe predhodnih izkopavanj, sočasno z njimi pa je tudi posodje, okrašeno s t.i. motivom sigme. Oblikovno so prisotne kroglaste posode in lonci z izraženim bikoničnim ostenjem, redkejše so odprte forme posodja. Groba keramika je okrašena pretežno z odtiskovanjem, lahko tudi z barbotinom. Sledi 2 . faza neolitske poselitve, ki pa je bilaže precej poškodovana s srednjeveškimi posegi oz. jamami. Glede na radiokarbonske datacije bi naj ta faza pripadala obdobju med 6. in 5. tisočletjem pr. n. št., vključuje pa tudi gradivo, katero je mogoče datirati v sredino 6. tisočletja pr. n. št. Čeprav se v njej nadaljuje predhodna keramična tradicija, pa je kot novost potrebno izpostaviti še proizvodnjo fine, črne polirane keramike bikoničnih oblik s krajšim izvihanim ustjem. Ob izkopavanjih v 70. letih je bila definirana tudi 3. neolitska kulturna faza, v kateri pa je bila dokumentirana tudi srednjeveška keramika. Tekom sondiranj v letu 2014 se je ponovno pokazalo, da so bile plasti 3 . faze precej poškodovane s kasnejšimi srednjeveškimi posegi, zaradi česar se je v njih nahajala oblica srednjeveških najdb. Leta 2014 je bila evidentirana tudi 4 . faza, katero pa lahko označimo za recentno in predstavlja najmlajše posege na sami lokaciji. Glede na povedano se lahko zaključi, da je osrednja neolitska tumba v Mogili, katere del predstavlja tudi Školska Tumba, ena od največjih in najmasivnejših tega časa v Pelagoniji (največja višina stratifikcije plasti dosega cca. $6 \mathrm{~m})$. Takšna višina naselbinskih plasti ne preseneča, glede na njen centralni značaj v odnosu do številnih, nekoliko manjših tumb, ki so registrirane v njeni neposredni bližini. Celotna prostorska situacija evidentiranih lokacij potrjuje, da ima Mogila centralno pozicijo med najdišči v tem delu Pelagonije, h kateri so gravitirali številni manjš̌ zaselki, ki so nastali bodisi v času neolitika ali tudi v katerem od kasnejših prazgodovinskih obdobij. Njena lokacija kakor tudi arheološko gradivo pričata, da je bila naselbina že v zgodnjem neolitiku v središču ekonom- 
skih tokov prvih poljedelcev v Pelagoniji in je znatno prispevala $\mathrm{k}$ učvrstitvi ekonomskih standardov in simboličnih principov zgodnje neolitskega obdobja.

\section{Summary}

The area of Pelagonia (North Macedonia) settlement has been known as an area of intensive Neolithic to the archaeological scientific community for quite some time. A great research interest for Pelagonian prehistoric sites emerged only after WWII. The first excavations were then carried out by Josip Korošec at Grgur Tumba; also, first basic archaeological excavation at the Tumba near Porodin has to be pointed out. The "golden age" of prehistoric studies of Pelagonia occurred in the 1970's, when systematic surveys as well as test probing were carried out at a number of locations in the central part of Pelagonia. At that time, systematic archaeological research was carried out at the sites of Veluška Tumba near Porodin, Mogila, Optičati, Trn, Karamani, Dobromiri, Radobor and elsewhere.

As a specific archaeological phenomenon, Pelagonia is now again becoming the focus of interest of the wider professional community. In the framework of this initiative, archaeological test probing was conducted in 2014 in the outskirts of Školska Tumba location in Mogila, in cooperation with the Macedonian - Slovenian team, aimed at recognizing the stratification of the settlement itself. Probing to a large extent confirmed the findings and results of the research, conducted in 1977 at the same location. The difference is only in identifying and defining the sequence of individual phases of the settlement, or so-called cultural horizons, namely another later phase has been recognised, which is objectified through the upper layers of the settlement. In this sense, we can confirm that we are dealing with a tumba (tell settlement) that has been formed in the Early Neolithic and lasted until its final phases. The site was also re-settled in the Middle Ages. We did not find any archaeological remains of younger phases of prehistory or antiquity.

Near the site of Mogila, a dozen of prehistoric settlements - tumbae has been recognised; some of them, e.g. Tumba Sredselo, Tumba Selska Crkva and Školska Tumba can be considered as a part of a single large settlement, which has been broken down into several micro locations by the modernization of the village Mogi- la. It is assumed that the location of Školska Tumba was only one integral part of a larger settlement, which is also confirmed by the exceptional similarity of the $\mathrm{Ne}$ olithic material found during the excavations at Tumba Sredselo in 1975 .

Archaeological probing in 2014 showed that four different settlement phases can be defined on the periphery of the Školska Tumba location. The oldest phase (first settlement phase) belongs to the early Neolithic, which is confirmed by architectural remains and uncovered archaeological finds, especially ceramic material. Radiocarbon dating confirms the established time span. The site was inhabited for the first time somewhat after the beginning of the sixth millennium, and the settlement was also confirmed at the transition between the sixth and the fifth millennium BC. Such a date completely corresponds with the beginning of settlement at the locations of Veluška Tumba and Tumba near Porodin, as well as Cuka near Topolčani. The earliest stage of the settlement is characterized by vessels with white painted ornamentation in the form of complex composition motifs of elongated lines, trace that has been already noticed in uncovered finds of previous excavations, and at the same time there are also vessels decorated with so-called sigma motives. Vessels are of rather globular forms and pots have a pronounced biconic shape, the more open forms of the containers are rare. The coarse pottery is predominantly decorated by stamping, and also with so-called barbotine. Second settlement phase of the Neolithic settlement was already significantly damaged by medieval pits and other interventions. According to radiocarbon dating, this phase should belong to the period between the $6^{\text {th }}$ and $5^{\text {th }}$ millennium $\mathrm{BC}$, however it also includes material that can be dated to the middle of the $6^{\text {th }}$ millennium BC. Although the previous ceramic tradition continues with this phase, it is also necessary to emphasize the production of fine, black polished biconical vessels with a short sputtered mouth. During the r97os excavations, the third Neolithic cultural phase was also defined, in which medieval ceramics was documented. During archaeological probing in 20I4, it was shown again that the layers of the $3^{\text {rd }}$ settlement phase were significantly damaged by subsequent medieval interventions, which caused the abundance of medieval finds within the layers of this phase. In 
20I4, phase 4 was also recorded, which represents the youngest interventions on the site itself.

According to the results, we can conclude that central Neolithic tumba in Mogila, part of which is represented also by Školska Tumba, is perhaps one of the largest and most massive structures of this time in Pelagonia (the maximum height of the stratification is approx. $6 \mathrm{~m}$ ). Such a height of settlement layers is not surprising given its central character in relation to many smaller tumbae that are recorded in its immediate vicinity. The entire spatial situation of documented locations confirms that Mogila has a central position among the sites in this part of Pelagonia, which was gravitated by many smaller settlements, which were created either in Neolithic times or in any of the later prehistoric periods. Its location as well as its archaeological material indicate that the settlement was already in the early Neolithic at the center of the economic flows of the first farmers in Pelagonia and has significantly contributed to the consolidation of economic standards as well as symbolic principles of the early Neolithic period.

\section{Literatura}

Andonovski, G. H. 1954. »Beleški za neolitot vo Makedonija.«Vesnik na muzejskokonzervatorskoto društvo na NRM I-2: 2-5. / Андоновски, Г. Х. 1954. »Бемешки за неолитот во Македонија.« Весник на музејско-конзерваторското Аруштво на HPM I-2: 2-5.

Galović, R. 1967. »Zelenikovo - neolitsko naselje«. Zbornik Narodnog Muzeja V: 127-67. / Галовиќ Р. 1967. Зелениковонеолитско населје. Зборник Народног Музеја V: 127-67.

Grbić, M., P. Mačkić, Š. Nadj, D. Simoska in B. Stalio. 1960. Porodin: kasnoneolitsko naselje na Tumbi kod Bitolja. Bitolj - Beograd: Narodni muzej Bitolj Arheološki institut.

Heurtley, W. A. 1939. Prehistoric Macedonia: An archaeological reconnaissance of Greek Macedonia (West of the Struma) in the Neolithic, Bronze and Early Iron Ages. Cambridge: Cambridge University Press.

Kitanoski, B. 1977. »Neolitska naselba Čuka kaj selo Topolčani.«Macedonia Acta
Archaeologica 3: 27-42. / Китаноски, Б. 1977. »Неолитска населба Чука кај село Тополчани. « Macedonia Acta Archaeologica 3: 27-42.

Kitanoski, B. 1989. »Vrbjanska Čuka.《 Arheoloski pregled 1987: 47-48. I Китаноски, Б. 1989. "Врбјанска Чука.” Arheološki pregled 1987: 47-48.

Kitanoski, B., D. Simoska in J. Todorović. 1978.

"Novi arheološki istražuvanja na naselbata Čuka vo Topolčani kaj Prilep.” Macedonia Acta Archaeologica 4: 9-32. / Китаноски, Б., А. Симоска in J. Тодоровић. 1978. “Нови археолошки истражувања на насе бата Чука во Тополчани кај Примеп." Macedonia Acta Archaeologica 4:9-32.

Kitanoski, B., D. Simoska in J. Todorović. 1980. "Naselbata Pešterica i problemot na raniot neolit vo Pelagonija." Macedoniae Acta Archaeologica 6: 9-20. / Китаноски, Б., А. Симоска in J. Тодоровић. 1980. "Населбата Пештерица и проблемот на раниот неолит во Пелагонија." Macedoniae Acta Archaeologica 6: 9-20.

Kitanoski, B., D. Simoska in J. Todorović. 1983. "Novi arheološki istražuvanja na naselbata Čuka vo Topolčani kaj Prilep.” Macedonia Acta Archaeologica 6: 9-20. / Китаноски, Б., А. Симоска in J. Тодоровић. 1983. “Нови археолошки истражувања на населбата Чука во Тополчани кај Примеп." Macedonia Acta Archaeologica 6: 9-20.

Kitanoski, B., D. Simoska in J. Todorović. 1990. Der kultplatz auf der fundstatte Vrbjanska Cuka bei Prilep. V Vinča and its World. International Symposium The Danubian Region from 6000-3000 BC, uredila D. Srejović in N. Tasić, I07-I2. Beograd: Serbian Academy of Science and Arts, Centre for Archaeological Research, Faculty of Philosophy.

Kuzman, P. 2013. Praistoriski palafitni naselbi vo Makedonija. V Makedonija: mileniumski kulturno-istoriski fakti, uredili P. Kuzman, E. Dimitrova in J. Donev, 
297-430. Skopje: Media Print. / Кузман, П. 2013. Праисториски палафитни населби во Македонија. V

Македонија: милениумски културноисториски факти, uredili П. Кузман, Е. Амитрова in J. Аонев, 297-430. Скопје: Медиа Принт.

Mitkoski, A. 2005. Sadova keramika od Vrbjanska Čuka. Macedoniae Acta Archaeologica 16: 29-53. / Миткоски, А. 2005. Садова керамика од Врбјанска Чука. Macedoniae Acta Archaeologica 16: 29-53.

Naumov, G. 2008. Imprints of the Neolithic Mind: Clay seals from the Neolithic Macedonia. Documenta Praehistorica XXXV: $185-204$.

Naumov, G. 2009. Procesot na neolitizacija vo Republika Makedonija. V Neolitskite zaednici vo Republika Makedonija, uredili G. Naumov, LJ. Fidanoski, I. Tolevski in A. Ivkovska, 19-27. Skopje: Dante. / Наумов, Г. 2009а. Процесот на неолитизација во Република Македонија. V Неолитските заедници во Република Македонија, uredili Г. Наумов, Ь. Фиданоски, И. Толевски in А. Ивковска, 19-27. Скопје: Аанте.

Naumov, G. 2010. Symmetry analysis of Neolithic painted pottery from Republic of Macedonia. V Data Management and Mathematical Methods in Archaeology, uredila K. T. Biró, 255-74. Archaeologia e Calcolatori 2r. Roma: Dipartimento Patrimonio Culturale.

Naumov, G. 20r. Visual and conceptual dynamism of the Neolithic altars in the Republic of Macedonia. V Interdisziplinäre Forschungen zum Kulturerbe auf der Balkanhalbinsel, uredili V. Nikolov, K. Bacvarov in H. Popov, 89-129. Sofia: Nice. Naumov, G. 20I4. Together We StandDivided We Fall: Fragmentation of Neolithic Figurines in Govrlevo and Zelenikovo, Republic of Macedonia. $\mathrm{V}$ Anthropomorphism and symbolic behaviour in the Neolithic and Copper Age communities of South-Eastern Europe, uredila C. Ursu in S. Terna, I6I-86. Suceava: Muzeul Bucovinei.

Naumov, G. 2015. Neolitskifigurini vo Makedonija. Skopje: Magor. / Наумов, G. 2015. Неолитски фигурини во Македонија. Скопје: Магор.

Naumov, G. 2016a. Survey on the prehistoric tell-sites in Pelagonia. PAST 82: 15.

Naumov, G. 2016b. Tell communities and wetlands in the Neolithic Pelagonia Republic of Macedonia. Documenta Praehistorica 44: 327-342.

Naumov, G. in S. Stojkoski. 2015. Novi predistoriski tumbi vo Pelagonija. Zbornik na trudovi na Zavod i muzej - Bitola I8: 169-83. / Наумов, Г. in С. Стојкоски. 2015. Нови преАисториски тумби во Пемагонија. Зборник на трудови на Завод и музеј - Битола І8: 169-83.

Naumov, G., M. Teržiecki, M. Pržibila, M. Čviej, U. Bugaj, P. Ščepanik, in M. Podsjadlo. 20I 4. Arheološko, topografsko i geofizičko istražuvanje na neolitski tumbi vo Pelagonija. Patrimonium I2: 345-72. / Наумов, Г., М. Тержиецки, М. Пржибима, М. Чвиеј, У. Бугај, П. Шчепаник, in Подсјадло, М. 2014. Археолошко, топографско и геофизичко истражување на неолитски тумби во Пемагонија. Патримониум г2: 345-72.

Simoska, D. 1986. Veluška Tumba, neolitska naselba. Arheološki Pregled 26: 48. I Симоска, А. 1986. Велушка Тумба, неолитска населба. Arheološki Pregled 26: 48.

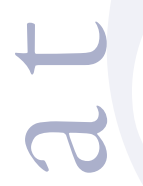
$1)$ $r$ r

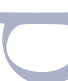
ska, D. 1988. Preliminaren izveštaj za I987 godina od arheološkite iskopuvanja na lokalitetot Tumba $v$ sred selo (Tumba I) selo Mogila. Neobjavljeno poročilo. / Симоска, A. 1988. Прелиминарен извештај за 1987 година од археолошките ископувања на мокалитетот Тумба в сред село (Тумба I) село Могима. Непубликуван извештај.

Simoska, D. in P. Kuzman. 1990. Tumba Optičari. Arheološki Pregled 1988: 63-66. I 
Симоска, А. in П. Кузман. 1990. Тумба Оптичари. Arheološki Pregled 1988: 63-66.

Simoska, D. in V. Sanev. 1975. Neolitska naselba Veluška tumba kaj Bitola. Macedoniae Acta Archaeologica I: 25-85. / Симоска, А. in B. Санев. 1975. Неолитска населба Вемушка тумба кај Битола. Macedoniae Acta Archaeologica I: 25-85.

Simoska, D. in V. Sanev. 1976. Praistorija vo Centralna Pelagonija. Bitola. Bitola: Naroden muzej Bitola. / Симоска, А. in В. Санев. 1976. Праисторија во Централна Пелагонија. Битола. Битола: Народен музеј Битола.

Simoska, D. in V. Sanev. 1977. Neolitska naselba na Mala Tumba kaj selo Trn, Bitola. Macedonia Acta Archaeologica 3: 215-37. / Симоска, А. іn В. Санев. 1977. Неолитска населба на Мала Тумба кај село Трн, Битола. Macedonia Acta Archaeologica 3: 215-37.

Simoska, D., B. Kitanoski, andin J. Todorović. 1976. Naselbata Crnobuki i problemot na istoimenata kultura vo svetlinata na novite arheološki istražuvanja. Macedonia Acta Archaeologica 2: 43-83. / Симоска, А., Б. Китаноски, in J. Тодоровиќ. 1976. Населбата Црнобуки и проблемот на истоимената култура во светлината на новите археолошки истражувања. Macedonia Acta Archaeologica 2: 43-83.

Simoska, D., B. Kitanoski, in J. Todorović. 1979. Neolitska naselba vo selo Mogila kaj Bitola. Macedonia Acta Archaeologica 5: 9-30. / Симоска, А., Б. Китаноски, in J. Тодоровиќ. 1979. Неолитска населба во село Могима кај Битола. Macedonia Acta Archaeologica 5: 9-30.

Simoska, D. 1996a. Mogila. V Arheološka karta na Republika Makedonija 2, uredila D. Koco in C. Grozdanov, 36. Skopje: MANU. / Симоска, A. 1996а. Могила. V Археолошка карта на Република Македонија 2, uredila $А$. Коцо in Ц. Грозданов, 36. Скопје: МАНУ.

Simoska, D. 1996b. Radobor. V Arheološka karta na Republika Makedonija 2, uredila D. Koco in C. Grozdanov, 39. Skopje:
MANU. / Симоска, А. 1996а. Могима. V Археолошка карта на Република Македонија 2, uredila $A$. Коцо in Ц. Грозданов, 39. Скопје: МАНУ.

Temelkoski, D. in A. Mitkoski. 200 I.

Neolitski antropomorfni statuetki vo predistoriskata zbirka od Zavod i muzej Prilep. Makedonsko nasledstvo 17: 53-69. I Темелкоски, A. in А. Миткоски. 200 I. Неолитски антропоморфни статуетки во преАисториската збирка од Завод и музеј Прилеп. Македонско наследство 17: 53-69.

Temelkoski, D. in A. Mitkoski. 2006. Praistoriska naselba Mogila, Senokos. Macedonia Acta Archaeologica 17: 558о. / Темелкоски, А. in А. Миткоски. 2006. Праисториска насемба Могима, Сенокос. Macedonia Acta Archaeologica 17: 55-80.

Temelkoski, D. in A. Mitkoski. 2008. Docnoneolitska naselba na lokalitetot Kutline kaj selo Rakle. Macedoniae Acta Archaeologica I8: 93-го8. / Темелкоски, А. in А. Миткоски. 2008. Аоцнонеолитска населба на мокалитетот Кутмине кај село Ракле. Macedoniae Acta Archaeologica I8: 93-I08.

Todorović, J., D. Simoska, in B. Kitanoski. 1980. Začetokot i razvojot na prvite zemjodelski zaednici vo neolitskiot period i nivniot premin vo metalno doba na podračjeto na Pelagonija. Neobjavljeno poročilo. Bitola. /Тодоровиќ, J., А. Симоска, in Б. Китаноски. 1980. Зачетокот и развојот на првите земјоделски заедници во неолитскиот период и нивниот премин во метално доба на подрачјето на Пелагонија. Непубликуван извештај. Битола. Veljanovska, F. 1996/97. Paleodemografiski karakteristiki na naselenieto na Makedonija od bronzeno vreme do sredniot vek. Macedoniae Acta Archaeologica I5: 40I-I4. 